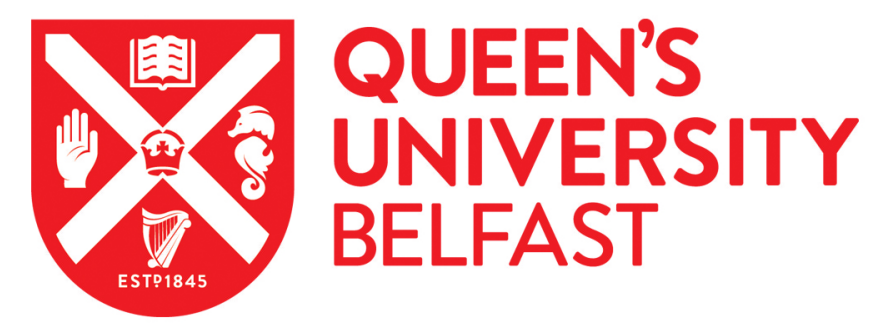

\title{
An Investigation of the Relationship Between Cross-Race Friendships and Attraction
}

Thai, M., O'Donnell, A. W., Turner, R. N., \& Barlow, F. K. (2021). An Investigation of the Relationship Between Cross-Race Friendships and Attraction. Personality and Social Psychology Bulletin.

Published in:

Personality and Social Psychology Bulletin

Document Version:

Peer reviewed version

Queen's University Belfast - Research Portal:

Link to publication record in Queen's University Belfast Research Portal

Publisher rights

Copyright 2021 SAGE. This work is made available online in accordance with the publisher's policies. Please refer to any applicable terms of use of the publisher.

\section{General rights}

Copyright for the publications made accessible via the Queen's University Belfast Research Portal is retained by the author(s) and / or other copyright owners and it is a condition of accessing these publications that users recognise and abide by the legal requirements associated with these rights.

Take down policy

The Research Portal is Queen's institutional repository that provides access to Queen's research output. Every effort has been made to ensure that content in the Research Portal does not infringe any person's rights, or applicable UK laws. If you discover content in the Research Portal that you believe breaches copyright or violates any law, please contact openaccess@qub.ac.uk. 
Thai, M., O'Donnell, A., Turner, R. N., \& Barlow, F. (in press). An investigation of the relationship between cross-race friendships and attraction. Personality and Social Psychology Bulletin.

An investigation of the relationship between cross-race friendships and attraction

Michael Thai

University of Queensland, Australia

Alexander O’Donnell

Flinders University, Australia

Rhiannon N. Turner

Queen's University Belfast, UK

Fiona Kate Barlow

University of Queensland, Australia 


\begin{abstract}
Four studies investigated the link between cross-race friendships and attraction. In Study 1, White Australian participants $(N=240)$ who reported friendships with racial outgroup members were more likely to report attraction to the racial group their friends belonged to. Studies $2 \mathrm{a}(N=300$ White American participants $)$ and $2 \mathrm{~b}(N=303$ White British participants) showed that non-verbal intimacy with the racial outgroup, perceived cross-racial reciprocity in attraction, positive perceived ingroup norms about dating cross-racially, and warmth towards the racial outgroup were particularly important in explaining the friendshipattraction link in majority samples. Study $3(N=292$ Black British participants) showed that self-disclosure was particularly important in explaining the friendship-attraction link for racial minority group members, in addition to the mediators above. These findings extend the contact literature by exploring the specificity and mediators of the link between contact and attraction in the context of race relations.
\end{abstract}

Keywords: intergroup contact; interracial relationships; cross-group friendships; race relations; attraction 


\section{An investigation of the relationship between cross-race friendships and attraction}

Intimate contact with various racial outgroup members (e.g., cross-group friendships) is reliably associated with a reduction in prejudice towards those racial outgroups (Davies et al., 2011; Marinucci et al., 2021). By extension, such intimate contact may also promote romantic attraction to racial outgroup members, who would otherwise be deemed undesirable by those high in racial prejudice (Herman \& Campbell, 2012). This notion is further supported by the literature on attraction, which shows people are more likely to be attracted to those with whom they are more familiar (Finkel et al., 2015). Indeed, preliminary evidence shows that contact predicts openness to forming romantic relationships with racial outgroup members (Brooks \& Neville, 2016; Coley et al., 2008). To date, however, little more is known about this link. The present research aims to assess (1) whether this association specifically emerges only for the racial outgroup a person has friends from, (2) what variables mediate this association, and (3) whether this pattern of mediation is consistent across racial majority and minority group members.

\section{Intergroup Attraction as an Indicator of Non-prejudice}

Research shows that many people are resistant to the idea of forming romantic or sexual relationships with a member of another race (Herman \& Campbell, 2012; Paterson et al., 2015). The rejection of potential partners based on race or ethnicity alone has been linked to general racial prejudice (Han, 2007; Thai, 2020). For example, attraction and romantic receptivity to members of racial outgroups (or lack thereof) is associated with racial stereotypes (Wilkins et al., 2011), intergroup anxiety and biases (Levin et al., 2007), and general warmth towards the relevant racial outgroups (Herman \& Campbell, 2012). People who disclose exclusive racial preferences when dating tend to score higher on indices of discrimination (Callander et al., 2015), and are also considered by observers to be more racist (Thai et al., 2019). 
Given that cross-race attraction is a possible indicator of underlying prejudice, established mechanisms that reduce prejudice, such as intergroup contact, may also mitigate intergroup biases during mate selection. Indeed, positive contact with racial outgroups is known to improve attitudes towards others' interracial relationships (Johnson \& Jacobson, 2005), and reduces reported social distance with racial outgroup members (Bastian et al., 2012). Paterson et al. (2019) recently demonstrated that participants' positive contact with a religious outgroup was significantly associated with their own receptivity to romantic relationships with members of that religious outgroup. By extension, this should mean that intimate contact with members of a racial outgroup, in the form of cross-race friendship, would be associated with greater attraction to that racial outgroup.

\section{The Laws of (Intergroup) Attraction}

The idea that cross-race friendships would be associated with greater attraction is also theoretically sustained by literature on interpersonal attraction. In particular, research on propinquity or familiarity effects shows that people tend to be more likely to develop romantic attraction toward those whom they frequently encounter and interact with (Aron et al., 1989; Finkel et al., 2015). Familiarity is considered a powerful determinant of attraction (Finkel et al., 2015). In the domain of cross-race attraction, cross-race friendships inherently promote familiarity, providing individuals greater opportunity for exposure and intimate interaction with racial outgroup members. Thus, cross-group friendships should facilitate the development of romantic and sexual attraction to members of these racial outgroups.

Although sparse, there is some evidence of the proposed cross-race friendshipattraction link. Coley and colleagues (2008) found that people with more cross-race friendships were more open to dating interracially. Further, Brooks and Neville (2016) examined predictors of White men's attraction to Black women and found that White men who had greater cross-race friendships with Black people reported more attraction to Black 
women whose (fictional) dating profiles they were shown. These studies provide preliminary support for the notion that cross-race friendships predict attraction.

\section{The Present Research}

The present research builds upon this nascent work by further elucidating the association between cross-race friendships and attraction to racial outgroup members in a number of ways. Study 1 establishes the base association by testing whether White participants' friendships with members of a number of racial minority outgroups predicts greater attraction to each of those racial outgroups. In doing so, we provide the first test of whether the friendship-attraction link is race-specific, or whether friendships with one racial outgroup can predict attraction to other racial outgroups. Studies $2 \mathrm{a}$ and $2 \mathrm{~b}$ aim to identify, for the first time, the potential mediators of the friendship-attraction association and replicate this pattern of association across two samples of White participants. Study 3 tests for the cross-race friendship-attraction link and mediators of this link in a sample of Black participants to determine whether there are majority-minority differences in this link ${ }^{1}$.

\section{Study 1}

Study 1 sought to establish whether the cross-race friendship-attraction link emerges for a variety of racial outgroups, as well as the racial specificity of the link. Coley and colleagues (2008) found that cross-race friendships predicted openness to interracial dating in a broader sense, rather than probing deeper to determine whether the effect was specific to only the racial outgroups participants' friends belonged to. Brooks and Neville (2016), on the other hand, examined the friendship-attraction association in the context of White-Black relations only. Study 1 extended upon this work by testing whether the relationship between cross-race friendships and attraction would emerge for a number of racial outgroups.

In this study, White Australian participants reported their friendships with six racial minority outgroups (i.e., Black, Asian, South Asian, Latinx, Middle-Eastern, Indigenous), as 
well as their attraction to these same six outgroups. Building on previous research on the prejudice-reducing effects of positive intimate contact (Davies et al., 2011), as well as the attraction-increasing effects of familiarity (Finkel et al., 2015), we hypothesized that friendships with members of a racial outgroup would predict greater attraction to that racial outgroup. We also took advantage of our assessment of the friendship-attraction link with multiple racial outgroups to test for secondary transfer effects (Pettigrew, 2009). Specifically, we sought to examine whether friendships with members of one racial outgroup might also predict attraction to members of other racial outgroups or whether they would only predict attraction to that specific racial outgroup.

Finally, we sought to rule out the alternative possibility that the link between crossrace friendship and attraction was a byproduct of a general orientation associated with hostility towards outgroups. We therefore measured social dominance orientation to include as a covariate in the present study. Given its hierarchy-enhancing ideology, those high in social dominance orientation would be more likely to reject both platonic and romantic relations with racial minority group members, especially those stereotyped as lower in status (Ho et al., 2015). In support of this, past work shows that social dominance orientation predicts opposition to interracial relationships and marriages (Lalonde et al., 2007).

\section{Method}

\section{Participants}

Participants were White Australian undergraduate students recruited from a first-year psychology course who were reimbursed with course credit for their participation. The final sample $\left(N=240 ; M_{\text {age }}=22.27, S D=7.18\right)$ comprised 169 female $(70.4 \%)$ and 71 male (29.6\%) participants, of whom 203 identified as heterosexual (84.6\%), 27 as bisexual (11.3\%), eight as gay (3.3\%), and two as "Other" (0.8\%). Sensitivity power analyses 
indicated sufficient power to detect a small-medium effect size $\left(f^{2}=.05-0.6\right)$ with $80 \%$ power across all studies in this paper.

\section{Measures}

Cross-race friendships. A two-item scale adapted from Turner et al. (2007) was used to measure participants' friendships with members of each of six racial outgroups specifically, Black, Asian, South Asian, Latinx, Middle-Eastern, and Indigenous people (i.e., "How many [group] friends do you have?" 1 = none at all, 5 = a great deal; "How often do you spend time with your [group] friends?" $1=$ never, $5=$ all the time). Items were averaged for an index of friendships with members of each outgroup (refer to the correlations tables for Cronbach's alphas). Ingroup (i.e., White) friendships were also assessed and controlled for, given that past research has shown that ingroup friendships can reduce positive attitudes towards outgroup members (Levin et al., 2003).

Cross-race attraction. Six items were developed to measure attraction to members of each of the racial outgroups. Three questions gauged the extent to which participants found members of the racial outgroup "physically attractive", "sexually desirable", and "romantically desirable" ( 1 = not at all, $7=$ extremely $)$. Three further questions asked participants whether they would "have sexual relations with", "have romantic relations with", and "marry" a member of the racial outgroup ( $1=$ strongly disagree, $7=$ strongly agree $)$. These items were combined and averaged to form an index of attraction to each racial outgroup.

Social dominance orientation. The sixteen item SDO7 scale (Ho et al., 2015) was used to measure social dominance orientation (e.g., "Some groups of people are simply inferior to others." 1 = strongly oppose, 7 = strongly favor). Items were averaged such that higher scores indicated greater social dominance orientation. 
Other covariates. Consistent with past work linking gender and sexual orientation to interracial dating preferences (Babbit, 2013), we also controlled for these variables in our analyses.

\section{Results}

Descriptive statistics and bivariate correlations are displayed in Table 1. Even at a bivariate level, the friendship-attraction links were largely race-specific - friendships with members of a racial outgroup was either only or tended to be more strongly associated with attraction to that specific racial outgroup.

Path analysis was used to explore the associations between cross-race friendships and attraction. Friendships with all racial outgroups were included in the model concurrently as predictors of attraction to each racial outgroup. The model is displayed in Figure 1. The inclusion of ingroup friendships with White people, gender, sexual orientation, and social dominance orientation did not alter the direction or significance of any pathway, but they were retained in the model as covariates. The path analysis was conducted in Mplus (v8.3; Muthén \& Muthén, 2017) using a maximum likelihood estimator. The results for each pathway are displayed in Table 2. Friendships with members of each racial outgroup were significantly positively associated with attraction to that specific racial outgroup, $\beta \mathrm{s} \geq .18, p \mathrm{~s}$ $\leq .007$, but no other racial outgroup, $\beta \mathrm{s} \leq-.14, p \mathrm{~s} \geq .063$. Ingroup friendships with White people was only significantly positively associated with attraction to Latinx people.

\section{Discussion}

Consistent with hypotheses, Study 1 demonstrated that cross-race friendships with Black, Asian, South Asian, Latinx, Middle-Eastern, and Indigenous people were consistently associated with attraction towards these racial outgroups. These relationships were largely race-specific, such that friendships with one racial outgroup predicted attraction to that specific racial outgroup, alone. The one exception to this emerged for attraction to Latinx 
people, which was also predicted by friendships with other White people. Considering it is possible for ethnically Latinx people to be racially White (Golash-Boza \& Darity Jr, 2008), this finding was not surprising. By and large, however, the predominantly race-specific associations between cross-group friendships and attraction observed in the present study suggests there may be no secondary transfer effect of contact (Pettigrew, 2009) in the domain of attraction, or that any secondary transfer effect that does exist is too small to be detected with the current sample. The observed racial specificity, even in the bivariate correlations, increases confidence that these relationships were not a result of common method variance (Lindell, \& Whitney, 2001).

In sum, Study 1 corroborated a link between friendships with a racial outgroup and attraction to members of that outgroup. Little is understood, however, about the mechanisms underlying this association. Study 2 was therefore designed to examine a number of potential mediators. Given the breadth of mediators we planned to assess in the following studies, and the fact that Study 1 had already established the racial specificity of the friendship-attraction link, it was deemed unfeasible and theoretically redundant to continue to assessing participants' perceptions regarding multiple outgroups. We therefore focused on examining the friendship-attraction link in just one intergroup context from Study 2 onwards.

Specifically, we made the decision to focus on White-Black relations in the U.S. (Study 2a) and the U.K. (Study 2b, 3). Black Americans and Black Britons represent large racial minority groups in both the U.S. and the U.K. In addition, there has traditionally been a strong focus on White-Black intergroup dynamics in social psychology, particularly within the intergroup contact literature (Pettigrew \& Tropp, 2006). Therefore, we decided to test the friendship-attraction link in this intergroup context to be able to better embed this work within the past literature.

\section{Study 2}


Study 2 aimed to extend upon Study 1 by exploring the mediators underlying the association between cross-race friendships and attraction. To date, no research has explored the mediators of this association. Although variables that mediate the traditional contactprejudice relationship may also mediate the cross-race friendship-attraction link, other factors pertinent to the domain of attraction may play a more pivotal role in explaining this association. Potential mediators to investigate were therefore drawn from disparate literatures on intergroup attitudes and intergroup contact research, as well as the broader literature in the area of attraction. These mediators were all tested to determine which were most important in explaining the friendship-attraction link.

\section{Intergroup Warmth}

First, the extent to which people have more favorable attitudes towards a racial outgroup more generally is perhaps the most proximal determinant of the degree to which they are attracted to members of that racial outgroup (Allport, 1954). Given previous direct evidence of both a link between contact and intergroup warmth (Davies et al., 2011; Pettigrew \& Tropp, 2006) and between intergroup warmth and attraction (Herman \& Campbell, 2012), we propose that intergroup warmth could explain the cross-race friendships-attraction relationship. Apart from being a potential direct mediator of this relationship, intergroup warmth might also function as a conduit through which other mediators are linked to attraction.

\section{Traditional Contact Mechanisms: Intergroup Anxiety, Empathy, and Trust}

It is possible that the traditional mechanisms explaining the relationship between contact and prejudice (e.g., intergroup anxiety, empathy, trust; Hayward et al., 2017; Pettigrew \& Tropp, 2008; Tam et al., 2009) also mediate the association between contact and attraction. Paterson and colleagues (2019) found little evidence of a direct mediating role of anxiety, trust, and empathy on the link between interreligious contact and romantic 
receptivity. These mediators, however, were robust predictors of interreligious warmth. Although the link between interreligious warmth and romantic receptivity was not tested in Paterson and colleagues' (2019) study, it is possible that these traditional contact mediators can indirectly predict cross-group attraction through warmth. That is, greater empathy and trust, and lower levels of anxiety, may allow for general warmth, which in turn is associated with desire.

\section{Attraction-centered Mechanisms: Perceived Similarity and Reciprocity}

Given that attraction is conceptually distinct from prejudice, other factors pertinent to attraction might play a more pivotal role in explaining the cross-race friendship-attraction relationship. Turning to the literature on attraction, similarity to a prospective partner is a key predictor of attraction; people tend to be attracted to those whom they perceive they are alike (Tidwell et al., 2013). Perceived similarity with outgroup members has, in turn, been shown to mediate the traditional contact-prejudice link (Gaertner et al., 2000). For example, Wright and Tropp (2005) showed that White students in integrated classes with Latinx students perceived greater similarity between themselves and Latinx children than those in segregated White-only classes, which in turn improved intergroup attitudes.

Reciprocity has also been identified as a key predictor of attraction; people tend to be attracted to those they believe are attracted to them and repelled by those they believe might romantically reject them (Eastwick et al., 2007). In the context of cross-race dating, research shows that people are more likely to cross racial boundaries when reciprocating romantic contact than initiating it (Lewis, 2013). Although the construct of perceived reciprocity has not been explored in the intergroup contact literature, it conceptually overlaps with idea of perceived outgroup norms, meta-perceptions, and (inversely) cognitions of rejection, which have been assessed as mediators of the traditional contact-prejudice link (Barlow et al., 2009; Techakesari et al., 2015; Turner et al., 2008). For example, Turner and colleagues (2008) 
found that extended intergroup contact induced more positive beliefs that the outgroup had favorable attitudes towards the ingroup, which was in turn associated with lower prejudice towards the outgroup.

Taken together, cross-race friendships may increase people's perceptions that members of the outgroup are similar to them and would be receptive to having intimate romantic relationships, increasing the chances for attraction, either directly or indirectly through promoting greater intergroup warmth.

\section{Intimacy Mechanisms: Self-Disclosure and Non-Verbal Intimacy}

Merely having racial outgroup friends does not automatically confer improvements to intergroup perceptions such as those outlined above (e.g., warmth, anxiety, empathy, trust, perceived similarity, reciprocity). Rather, this positive change emerges as a result of having extended intimate experiences with such friends (Davies et al., 2013; Turner \& Feddes, 2011). Theoretically, individuals are likely to experience verbal (e.g., self-disclosure) and non-verbal intimacy (e.g., physical touch, smile) in the context of friendships (Reis \& Shaver, 1988). If these friendships are cross-racial, this heightened verbal and non-verbal intimacy may improve the above intergroup perceptions (Davies et al., 2013), increasing preparedness for, and openness to the possibility of, a cross-race romantic partner with whom such forms of intimacy are expected.

Verbal intimacy, especially that which takes the form of self-disclosure, promotes closeness in interpersonal relationships, both platonic and romantic (Collins \& Miller, 1994; Laurenceau et al., 1998). Self-disclosure is both an established mediator of the contactprejudice relationship, and a mechanism that links positive contact to the other mediators of the contact-prejudice relationship, including intergroup anxiety, empathy, and trust (Tam et al., 2009; Turner \& Feddes, 2011; Turner et al., 2007). The attraction literature also shows that self-disclosure promotes greater perceived similarity (Sprecher et al., 2013) and 
perceived partner responsiveness, essentially reciprocity, in intimate relationships (Shelton et al., 2010). Thus, self-disclosure is a gateway through which cross-race friendships produce positive change (Davies et al., 2013), and may thus potentially account for increased attraction following friendships.

Like verbal intimacy, non-verbal intimacy, such as smile and touch, has also been shown to escalate intimate relationships by promoting psychological closeness and attraction (Givens, 1978). Although the intergroup contact literature has not yet examined the association between positive contact and non-verbal intimacy behaviors, there is research that has linked friendship to greater non-verbal intimacy behaviors and physical contact (Monsour, 1992). Thus, non-verbal intimacy may function, as verbal intimacy does, to explain the cross-race friendship-attraction link. In fact, given the visual and tactile nature of sexual and romantic attraction (Singer, 1984), non-verbal intimacy may be an even more powerful mechanism than verbal intimacy in this specific context.

\section{Normative Mechanisms: Perceived Ingroup Dating Norms}

Paterson et al. (2019) found that perceived ingroup dating norms were a robust mediator of the relationship between interreligious contact and romantic receptivity - the more positive contact participants had with members of a religious outgroup, the more they perceived that their friends and parents would be supportive of them dating a member of that religious outgroup, and in turn, the more receptive they were to dating or marrying a member of that religious outgroup. The role of ingroup dating norms have also been demonstrated in the context of race, wherein social network approval predicts dating within and outside racial group boundaries (Liu et al., 1995). We therefore investigate perceived ingroup dating norms as a mechanism to explain the cross-race friendship-attraction link in tandem with the other mechanisms described above.

\section{The Proposed Model}


Based on the literature above, Study 2 aimed to test a model whereby cross-group friendship predicts intimacy behaviors (i.e., greater self-disclosure and non-verbal intimacy), which in turn predicts traditional contact mechanisms (i.e., lower anxiety, higher empathy and trust) and attraction-centered mechanisms (i.e., greater perceived similarity and reciprocity). The concurrent mediating role of perceived ingroup dating norms was also examined. The link between these mechanisms and cross-race attraction, both directly and indirectly (through warmth), was tested. The full proposed model ${ }^{2}$ is displayed in Figure 2. These relationships were examined across two studies. First, the model was tested in a sample of White American participants in the context of attraction to Black people (Study 2a). This study was then replicated with a sample of White British participants again in the context of attraction to Black people (Study 2b).

\section{Method}

\section{Participants}

Study 2a. White American participants were recruited from Prolific Academic, an online subject pool widely used in social psychological and behavioral research (Peer et al., 2017). The final sample $\left(N=300 ; M_{\text {age }}=31.01, S D=10.86\right)$ comprised 107 female $(35.7 \%)$, 188 male (62.7\%), and 5 non-binary (1.7\%) participants, of whom 217 identified as heterosexual (72.3\%), 49 as bisexual (16.3\%), 20 as gay (6.7\%), and 14 as "Other" (4.7\%). Participants were paid $£ 0.50$ for their participation.

Study 2b. White British participants were recruited from Prolific Academic. The final sample $\left(N=303 ; M_{\text {age }}=37.85, S D=13.07\right)$ comprised 195 female $(64.4 \%), 107$ male (35.3\%), and 1 "Other"-identifying (0.3\%) participant, of whom 265 identified as heterosexual (87.5\%), 26 as bisexual (8.6\%), 9 as gay (3.0\%), and 3 as "Other" $(1.0 \%)$. Participants were paid $£ 2$ for their participation.

\section{Measures}


Studies $2 \mathrm{a}$ and $2 \mathrm{~b}$ employed the same measures. Items within each scale were averaged to form an index of the variable being measured.

Cross-race friendships. Friendships with Black people was measured as per Study 1.

Cross-race attraction. Attraction to Black people was measured as per Study 1, with the addition of one more item (for a seven-item scale) asking participants whether they would "date" a Black person.

Intergroup warmth. A feeling thermometer (Pettigrew \& Tropp, 2006) measured warmth towards Black people (i.e., "On a scale of $0-100$, please rate the warmth of your feelings toward Black people", $0=$ cold, $100=$ warm).

Intergroup anxiety. Four items adapted from Stephan and Stephan (1985) measured anxiety toward Black people (e.g., "I would feel uncomfortable when interacting with a Black person", 1 = strongly disagree, 7 = strongly agree).

Intergroup empathy. Five items adapted from Tam and colleagues (2009) measured empathy toward Black people (e.g., "When thinking about Black people, to what extent do you feel compassionate", $1=$ not at all, 7 = extremely).

Intergroup trust. Two items were developed to measure trust toward Black people (e.g., "I feel like I can trust Black people.”, 1 = not at all, 7 = very much).

Perceived similarity. Three items adapted from Henderson-King and colleagues (1997) measured perceived similarity to Black people (e.g., "How similar do you think you are to Black people", 1 = not at all similar, $7=$ extremely similar).

Perceived reciprocity. Four items were adapted from Turner and colleagues (2008) to measure participants' beliefs about whether Black people would be interested in forming romantic relations with them (e.g., "To what extent do you think that a Black person would be willing to have romantic relations with you?", $1=$ not at all, $7=$ extremely). 
Self-disclosure. Three items adapted from Turner et al. (2007) measured amount of self-disclosure to Black people (e.g., "How often do you talk about how you are feeling to someone Black?", 1 = never, 7 = always).

Non-verbal intimacy. Four items were developed to measure non-verbal intimacy behaviors with Black people (e.g., "How often do you hug someone Black?", 1 = never, 7 = always).

Perceived ingroup dating norms. Two items adapted from Paterson and colleagues (2019) measured perceptions of support for a romantic relationship with a Black person in their close circles (e.g., "How do you think your friends would feel about you dating a Black person?", 1 = very negatively, 7 = very positively).

Covariates. To account for previous romantic engagement with Black people, which could exert influence on attraction to Black people (Allen \& Uskul, 2019), one item was adapted from Paterson and colleagues (2019) to be used a covariate in analyses (i.e., "How many previous intimate relationships (sexual or romantic) have you had with a Black person?"). Participants responded with a numerical value. Gender and sexual orientation were also controlled for, as per Study 1.

\section{Results}

Descriptive statistics and bivariate correlations for Studies $2 \mathrm{a}$ and $2 \mathrm{~b}$ are displayed in Tables 3 and 4, respectively. For both studies, path analyses were computed to examine the indirect effect of cross-race friendships on attraction, via the proposed mechanisms. The full model (Figure 2) was estimated using maximum likelihood in Mplus. After examining the direct effects and total indirect effect of cross-race friendships on attraction, we computed the combined indirect effects for ingroup dating norms, self-disclosure, and non-verbal intimacy. Much like how the total indirect effect is an aggregate of each of the specific mediation pathways between cross-race friendships and attraction, these combined indirect effects are 
an aggregate of each of the specific indirect pathways running through these parallel mediators ${ }^{3}$. By examining the statistical significance of these combined indirect effects, we can easily assess the overall importance of these key mediating variables and avoid drawing inappropriate conclusions from potentially small and spurious specific indirect effects. Significant combined indirect effects were then dissected into their composite parts, and the specific indirect effects were examined. The significance of each indirect effect was determined using bias-corrected and bootstrapped 95\% confidence intervals (Hayes, 2009). The specific indirect effects are reported in Table 6 . The reported results focus on significant effects replicated in both studies.

\section{Direct Effects}

As outlined in Table 5, cross-race friendships predicted greater self-disclosure, greater non-verbal intimacy, and more positive ingroup dating norms across both studies. Selfdisclosure was not consistently related to any of the subsequent outcomes, but non-verbal intimacy predicted lower anxiety, and greater empathy, trust, similarity, and reciprocity. Subsequently, warmth was significantly predicted by ingroup dating norms, anxiety, empathy, trust, and similarity.

Importantly, participants who reported greater trust, greater reciprocity, and more positive ingroup dating norms, reported greater attraction to Black people in Study 2a, but only reciprocity was related to attraction in Study $2 \mathrm{~b}$. Finally, warmth predicted greater attraction to Black people. Empathy and similarity did not significantly predict attraction to Black people in either study.

\section{Indirect Effects}

Overall, cross-race friendships were significantly and positively indirectly associated with attraction across both studies. As shown in Figure 3, the combined indirect effects via 
non-verbal intimacy and ingroup dating norms were significant. In contrast, the combined indirect effect via self-disclosure was not significant in either study.

Non-verbal intimacy mediated the association between cross-race friendships and attraction via a number of specific pathways (see Table 6). First, cross-race friendships predicted greater non-verbal intimacy, which in turn directly predicted greater attraction via trust and reciprocity. Another four significant specific indirect effects running from nonverbal intimacy through to greater warmth and subsequent attraction emerged via lower anxiety, and greater empathy and similarity. In addition to the non-verbal intimacy mechanisms, the cross-race friendship-attraction relationship was also significantly mediated by ingroup dating norms, both directly, and via warmth.

There were two specific indirect effects from cross-race friendships via non-verbal intimacy that were significant in Study $2 b$ that did not emerge in Study 2a. The first was from non-verbal intimacy to attraction through similarity, and the second was from non-verbal intimacy to warmth and subsequently attraction through reciprocity.

\section{Discussion}

Consistent with hypotheses, Study $2 \mathrm{a}$ and $2 \mathrm{~b}$ demonstrated that having cross-race friendships was associated with attraction. They also extended upon Study 1 by highlighting several important mediators of this association. Non-verbal intimacy emerged as an important, novel mechanism linking cross-race friendships to attraction, predominantly by increasing perceptions that the racial outgroup would reciprocate attraction. In addition, nonverbal intimacy was also associated with intergroup warmth through decreased anxiety and increased empathy, trust, and perceived similarity, consistent with the broader literature on the contact-prejudice association (Hayward et al., 2017; Pettigrew \& Tropp, 2008; Tam et al., 2009). Intergroup warmth, in turn, predicted greater attraction. In line with Paterson and 
colleagues (2019), perceived ingroup dating norms emerged as the other important mediator of the friendship-attraction link.

\section{Study 3}

Study 3 aimed to explore the cross-race friendships-attraction association as well as the mediators underlying this association in a racial minority sample. Romantic relationships and intimate partnerships are, by definition, dyadic activities undertaken consensually due to a reciprocated interest. It is therefore important to examine antecedents of cross-race attraction from the perspective of racial minority group members. Given the power structures that have differentially governed their lived experiences, cross-race friendships may hold a different meaning for racial minority group members, leading to disparate outcomes (e.g., Barlow et al., 2013; Tropp \& Pettigrew, 2005; although see Barlow et al., 2019). There is also evidence that different mediators emerge as most important in explaining the contactprejudice association for racial majority group members compared to minority group members (Hayward et al., 2017).

Study 3 sought to test the proposed model (Figure 2) with Black British participants, in the context of attraction to White people. Although the above literature suggests that the contact-prejudice association can differ for racial minority group members, no firm hypotheses were made regarding the mechanisms in the present study, given this represented the first investigation into the mediators of the cross-race friendship-attraction association from a minority perspective.

\section{Method}

\section{Participants}

Black British participants were recruited from Prolific. The final sample $(N=292$; $\left.M_{\text {age }}=31.05, S D=9.25\right)$ comprised 210 female $(71.9 \%), 81$ male $(27.7 \%)$, and 1 "Other"identifying (0.3\%) participant, of whom 275 identified as heterosexual (94.2\%), 12 as 
bisexual (4.1\%), 2 as gay (0.7\%), and 3 as "Other" (1.0\%). Participants were paid $£ 2$ for their participation.

\section{Measures}

All variables were measured using the same scales from Study 2 (except here, Black participants answered these questions in reference to White people).

\section{Results}

Descriptive statistics and bivariate correlations are displayed in Table 7. The model tested and analytical approach was identical to Study 2.

\section{Direct Effects}

As outlined in Table 5, cross-race friendships predicted greater self-disclosure, greater non-verbal intimacy, and more positive ingroup dating norms. In turn, self-disclosure predicted greater trust, empathy, similarity, and reciprocity, but did not predict anxiety. Nonverbal intimacy predicted lower anxiety, and greater trust, similarity, and reciprocity, but did not predict empathy. In turn, warmth was significantly predicted by anxiety, empathy, trust, and reciprocity, but not predicted by ingroup dating norms or similarity.

Importantly, Black participants who reported greater trust, greater similarity, greater reciprocity, and more positive ingroup dating norms, reported greater attraction to White people. Further, warmth predicted attraction to White people. Anxiety and empathy did not significantly predict attraction to White people.

\section{Indirect Effects}

Overall, cross-race friendships were significantly and positively indirectly associated with attraction. As shown in Figure 3, the combined indirect effects via non-verbal intimacy and ingroup dating norms were significant. Unlike for White participants in Studies 2a and $2 b$, the combined indirect effect via self-disclosure was also significant for Black participants. 
Non-verbal intimacy again mediated the association between cross-race friendships and attraction via a number of specific pathways. First, cross-race friendships predicted greater non-verbal intimacy, which in turn directly predicted greater attraction via trust $(b=$ $\left..02, \mathrm{CI}_{95 \%}[.002, .06]\right)$ and reciprocity $\left(b=.04, \mathrm{CI}_{95} \%[.01, .08]\right)$. Another three significant specific indirect effects running from non-verbal intimacy through to greater warmth and subsequent attraction emerged via lower anxiety $\left(b=.01, \mathrm{CI}_{95} \%[.003, .03]\right)$, and greater trust $\left(b=.01, \mathrm{CI}_{95 \%}[.01, .04]\right)$, empathy $\left(b=.01, \mathrm{CI}_{95 \%}[.001, .02]\right)$, and reciprocity $\left(b=.01, \mathrm{CI}_{95 \%}\right.$ $[.001, .02])$. In addition to the non-verbal intimacy mechanisms, the relationship between cross-race friendships and attraction was again significantly mediated by ingroup dating norms $\left(b=.15, \mathrm{CI}_{95 \%}[.08, .24]\right)$.

Examining the composite parts of the significant combined indirect effect of selfdisclosure that emerged exclusively for Black participants in this study provided evidence that the relationship between cross-race friendships and attraction was mediated by trust $(b=$ $\left..04, \mathrm{CI}_{95 \%}[.01, .09]\right)$ and reciprocity $\left(b=.05, \mathrm{CI}_{95 \%}[.02, .10]\right)$. In addition, self-disclosure predicted greater warmth and subsequent attraction via higher empathy $\left(b=.01, \mathrm{CI}_{95 \%}\right.$ $[.01, .03])$, trust $\left(b=.03, \mathrm{CI}_{95 \%}[.01, .05]\right)$, and reciprocity $\left(b=.01, \mathrm{CI}_{95 \%}[.001, .02]\right)$.

\section{Discussion}

Study 3 established an association between cross-race friendships and attraction in a sample of racial minority participants. Whereas some mechanisms explaining this association were similar to those that emerged for White participants in Studies 2a and 2b, this study also highlighted mechanisms exclusive to racial minority group members. Consistent with findings for White participants, non-verbal intimacy emerged as a key mechanism linking cross-race friendships to attraction. For Black participants, non-verbal intimacy predicted increased attraction to White people through its association with greater trust in White people and perceptions that White people would reciprocate attraction. In addition, non-verbal 
intimacy predicted greater intergroup warmth through its association with lower anxiety and greater trust and perceived reciprocity. Intergroup warmth, in turn, predicted greater attraction. Perceived ingroup dating norms again emerged as another important mediator of the friendship-attraction link for Black participants as it did for White participants.

The present study also elucidated the important role that self-disclosure uniquely plays in racial minority group members' attraction to members of the White majority. Selfdisclosure, similar to non-verbal intimacy, also predicted Black participants' attraction to White people though its association with greater trust in White people and perceptions that White people would reciprocate attraction. In addition, self-disclosure predicted increased intergroup warmth through intergroup empathy, trust, and perceived reciprocity.

\section{General Discussion}

The present research investigated the relationship between cross-race friendship and attraction. Study 1 established the cross-race friendship-attraction association and tested its specificity in a sample of White Australian participants, Studies $2 \mathrm{a}$ and $2 \mathrm{~b}$ examined mediators of the association in two majority samples (i.e., White American, White British), and Study 3 explored these relationships in a minority sample (i.e., Black British). Together, these studies produced a number of novel contributions to the intergroup contact and interpersonal attraction literatures.

\section{Robustness and Specificity of the Cross-Race Friendship-Attraction Association}

The four studies collectively established and replicated a cross-race friendshipattraction link across both majority and minority samples, reinforcing preliminary evidence of such a relationship in past work (Coley et al., 2008; Brooks \& Neville, 2016). Study 1 further demonstrated, for the first time, that the cross-race friendship-attraction association is largely race-specific - friendships with members of one racial outgroup only reliably predicted attraction to that specific outgroup. This apparent absence of a secondary transfer effect 
(Pettigrew, 2009) in the domain of cross-race attraction suggests an important theoretical distinction between intergroup prejudice and attraction. One possible reason for this distinction is that prejudice may be more monolithic in nature, whereas attraction may be more outgroup-specific.

Previous work shows that people who are prejudiced towards one outgroup (e.g., Black people) usually tend to be prejudiced towards others (e.g., Asian people), and that this can be accounted for by an underlying generalized prejudice factor (Akrami et al., 2010). Thus, if positive contact reduces prejudice towards one racial outgroup, these positive attitudes may more easily generalize to other outgroups, given they are connected by an amorphous, non-specific prejudice. On the other hand, attraction to a racial outgroup may depend on the specific experiences an individual has had with members of that outgroup. Indeed, attraction is more visceral and visual than intergroup attitudes are (Singer, 1984). Attraction is also largely determined by favorable assessments of physical attractiveness. Given that different racial outgroups possess distinct phenotypes (i.e., physical attributes characteristic of their racial group), developing an appreciation for one racial phenotype through close friendships with members of that particular racial group may not necessarily translate into physical attraction to other racial phenotypes. Future research should continue to explore the qualities of intergroup attraction that differentiates it from prejudice.

\section{Mediators of the Cross-Race Friendship-Attraction Association}

Studies $2 \mathrm{a}, 2 \mathrm{~b}$, and 3 were the first to determine the most robust mediators of the cross-race friendship-attraction link across both racial majority and minority group members. Consistent with Paterson and colleagues' (2019) findings on interreligious attraction, perceived ingroup dating norms also explained the friendship-attraction relationship. People with more friendships with members of a racial outgroup perceived their friends and family would be more supportive of them dating that outgroup, and were in turn more attracted to 
members of that outgroup. These findings are consistent with the idea that having intimate contact in the form of friendships with members of a different racial group can shape perceptions of the normative acceptability of developing more intimate relationships with that racial outgroup.

The present research also introduced non-verbal intimacy as an unexplored intimacy mechanism. Physical contact and other friendly non-verbal signalling across racial lines played a key role in promoting positive intergroup feelings and perceptions that, in turn, predicted attraction. One important mechanism facilitated by non-verbal intimacy was that of perceived reciprocity. Sharing intimate, non-verbal interactions with racial outgroup members bolstered impressions that members of the racial outgroup would reciprocate attraction, which directly predicted one's own attraction to that outgroup. Non-verbal intimacy also facilitated traditional contact mechanisms - reducing anxiety and increasing empathy and trust - which promoted greater intergroup warmth, in line with the broader contact literature (Hayward et al., 2017; Pettigrew \& Tropp, 2008; Tam et al., 2009). Feeling more favorable towards a racial outgroup was, in turn, associated with outgroup attraction.

Although the rationale for non-verbal intimacy was grounded in the well-established literature examining verbal intimacy (i.e., self-disclosure) as a contact mechanism, it unexpectedly emerged as a stronger and more reliable mediator of the relationship between cross-race friendship and the other variables in the model when tested alongside selfdisclosure. Thus, the present findings suggest that, far from being a mechanism unique to explaining the contact-attraction link, non-verbal intimacy may play an important role in explaining the contact-prejudice link, more broadly. Indeed, non-verbal communication may often be a more powerful communicative tool than verbal communication (Hinde, 1972). The present research should therefore set in motion a new line of inquiry into non-verbal intimacy as a contact mediator. 


\section{Majority and Minority Differences in the Cross-Race Friendship-Attraction Association}

Although non-verbal intimacy eclipsed self-disclosure in explaining the cross-race friendship-attraction relationship for White participants, Study 3 showed that self-disclosure played a particularly important role in explaining this link for Black participants. Working much in the same way as non-verbal intimacy, self-disclosure was also associated with the traditional contact mechanisms of lower anxiety and higher empathy and trust, which predicted greater intergroup warmth and attraction. It also predicted feelings of reciprocity in attraction, which directly predicted greater cross-race attraction.

These findings show that racial minority group members may place greater emphasis on verbal intimacy than majority group members do when it comes to developing cross-race attraction. This may be attributed to their differential approaches to verbal intimacy in a broader sense. For example, Olson and colleagues (2018) found that Black participants perceived the conversational topics they generated when getting to know a new acquaintance to be more intimate than White participants perceived theirs to be. Research suggests that it is particularly important for racial minority group members to be able to disclose their experiences of racism, inequality, and cultural differences to White people with whom they wish to form interracial relationships (Foeman \& Nance, 2002). Being able to mutually disclose about such experiences, which are often hidden and ignored by White people, and getting positive responses from White friends may be key to opening up warmth and openness to developing more intimate relationships with a White partner. Future research should build on this work by continuing to elucidate the differential needs of racial majority and minority group members when it comes to contact.

\section{Broader Contributions to the Literature}

The present research extends upon work on propinquity and familiarity effects in the domain of romantic attraction (Aron et al., 1989; Finkel et al., 2015) by demonstrating that 
greater familiarity to members of a racial outgroup, in the form of cross-group friendships, can breed romantic and sexual attraction to those outgroups. In doing so, this work also contributes to the literature on interracial relationships, more specifically. Although many scholars have argued that the willingness to form intimate romantic relationships with members of a racial outgroup is an important barometer of abolished racial boundaries (Allport, 1954), very little research has examined the link between intimate contact and this indicator of racial prejudice. The present research advances the contact literature by explicating this underexplored association.

This work also helps to uncover aspects of the contact experience itself that can facilitate positive change. Contact has been described as a "black box" where people enter an experience and leave as a different person (Harwood, 2010; Ioannou \& Panagiotou, 2020). It is understood that contact experiences can reduce prejudice through established mediators, but considerably less is known about the experience itself and whether different experiences lead to different outcomes (Keil \& Koschate, 2020). By introducing non-verbal intimacy as a novel mechanism alongside verbal self-disclosure, the present research has provided additional insight into the variable experiences of intergroup interactions, thus advancing our understanding of what lies within the "black box" of positive contact.

The fact that non-verbal intimacy had not been previously considered as a contact mediator also highlights the tendency of the contact literature to intellectualize the lived experience of those involved in intergroup contact. A disproportionate focus on the more theoretical cognitive and affective mediators of contact has diverted attention from the behavioral mechanisms that exemplify the contact experience. Friendships and close intimate relationships are embodied, and it may be that these experiences go further to change our attitudes than do colder and more deliberate rationalizations.

\section{Limitations \& Future Directions}


As the study was cross-sectional, no causal conclusions could be drawn regarding the relationship between cross-race friendships and attraction. Although the relationship is framed such that cross-race friendships promotes attraction, it is also possible (and indeed likely) that greater attraction to particular racial outgroups encourages people to selectively develop more friendships from those outgroups. Previous research has established that the contact-prejudice link is bi-directional (Pettigrew, 2008), and it is likely that the relationships demonstrated in the present study work in the same way. Also, while the proposed mediation model was grounded in past work, it is just one of many theoretically viable configurations of the relationships between these variables. Future research should employ longitudinal designs to explore the temporal nature and (bi)directionality of the observed relationships.

Experiments using manipulations of intimate cross-racial contact in the lab (e.g., the "Fast Friends" procedure; Aron et al., 1997), may further elucidate whether cross-race contact can causally facilitate outgroup attraction.

Another limitation of the present research was that we did not account for the geographic proximity of participants to different racial outgroups, or in other words, the diversity of their immediate environment. Being more proximal to racial outgroup members may, separately, promote both cross-group friendships and intergroup attraction (Emerson et al., 2002; Fujino, 1997), and this may contribute to explaining the overall friendshipattraction relationship observed in the present work. Alternatively, it is possible that proximity is a necessary precursor to the friendship-attraction link, in that it could increase the likelihood that an individual would form cross-race friendships, which would in turn, facilitate attraction.

We note, however, geospatial data now largely confirms that individuals predominantly interact with their ingroup, even in highly diverse settings (Dixon et al., 2020). While undoubtedly important, the generally low levels of intergroup contact across societies 
suggest that proximity may not be sufficient on its own to increase cross-race attraction. Furthermore, proximity could not account for certain processes that were tested in the present work, such as self-disclosure or non-verbal intimacy, which are most likely to be gained through close contact. Self-disclosure and non-verbal intimacy are known to foster attraction and cannot be assumed to automatically emerge in diverse settings. Nevertheless, future longitudinal research should assess geographic proximity to racial outgroups alongside measures of cross-race friendships and attraction. This would allow us to better model the temporal relationships between these variables and further contribute to our understanding of the developmental trajectory of cross-race friendships and romantic relationships.

It should be noted that the items used to measure cross-race friendships in the present research were subjective and not as precise as would be ideal. For example, participants may not have had a clear, standardized reference or norm they could use to gauge whether they had "a little" or "a lot" of outgroup friends. Despite the imperfect nature of these items, however, the relationship between the two cross-race friendship items was strong across all studies, speaking to the reliability of the scale. In addition, the scale was reliably associated with all mediator variables and attraction across all studies in a theory-consistent manner. Thus, the scale demonstrated robust predictive validity. Nevertheless, future research should deploy improved measures of cross-race friendships to assess the friendship-attraction relationship

Future research should also explore the nuances of the link between cross-group friendships and attraction. For example, whereas the present work focused on cross-race friendships, it would be beneficial to determine whether superficial positive contact with racial outgroup members would also be associated with greater attraction. Past evidence that mere contact reduces prejudice (Pettigrew \& Tropp, 2006) and mere exposure increases attraction (Finkel et al., 2015), would suggest that contact would still be associated with 
attraction in the same way friendship was found to be in the present work. Relatedly, future work should explore the differential impact of contact quantity and quality on attraction. Past research that has differentiated between these two dimensions shows that contact quantity is associated with more positive implicit attitudes and contact quality is associated with more positive explicit attitudes (Tam et al., 2006). It is possible that the link between contact and attraction follows similar patterns. The present work provides a foundation from which future work can explore this nuance.

\section{Conclusion}

The present research builds upon the contact literature by demonstrating that crossrace friendships are associated with greater attraction to racial outgroup members (Studies 1, 2a, 2b, 3), and establishing the racial specificity of this link (Study 1). We also introduce nonverbal intimacy is an important mechanism of this link that predicts attraction via both perceived reciprocity in attraction and warmth (through the traditional contact mediators;

Studies $2 \mathrm{a}, 2 \mathrm{~b}, 3)$. For racial minority group members, we highlight the additional importance of self-disclosure as a mechanism explaining this link (Study 3). These findings speak to the complex association between cross-race friendship and desire and to the broader potency of contact as a force to abolish intergroup boundaries. 


\section{Notes}

1. Data for Studies $1-3$ can be accessed through the Open Science Framework: https://osf.io/dtj3c/?view_only=dc225866f9734d90b3de435439758cfc

2. Although the hypothesized model was informed by the extant literature examining each mediator separately, it is just one of many theoretically viable configurations of the relationships between these variables. Given the relative paucity of research examining all these mediators together, our test of this proposed model can be considered largely exploratory.

3. The combined indirect effects for self-disclosure, non-verbal intimacy, and ingroup dating norms was comprised of 10, 10, and 2 specific pathways, respectively. Only significant indirect effects are reported in text, but an overview of all specific indirect effects across all studies are included in Table 6. 


\section{References}

Allen, C. K., \& Uskul, A. K. (2019). Preference for dating out-group members: Not the same for all out-groups and cultural backgrounds. International Journal of Intercultural Relations, 68, 55-66. https://doi.org/10.1016/j.ijintrel.2018.11.002

Allport, G. W. (1954). The nature of prejudice. Reading, MA: Addison-Wesley.

Akrami, N., Ekehammar, B., \& Bergh, R. (2011). Generalized prejudice: Common and specific components. Psychological Science, 22(1), 57-59. https://doi.org/10.1177/0956797610390384

Aron, A., Melinat, E., Aron, E. N., Vallone, R. D., \& Bator, R. J. (1997). The experimental generation of interpersonal closeness: A procedure and some preliminary findings. Personality and Social Psychology Bulletin, 23(4), 363-377. https://doi.org/10.1177/0146167297234003

Babbitt, L. G. (2013). An intersectional approach to Black/White interracial interactions: The roles of gender and sexual orientation. Sex Roles, 68(11-12), 791-802. https://doi.org/10.1007/s11199-011-0104-4

Barlow, F. K., Hornsey, M. J., Hayward, L. E., Houkamau, C. A., Kang, J., Milojev, P., \& Sibley, C. G. (2019). Why do we hold mixed emotions about racial out-groups? A case for affect matching. Psychological Science, 30(6), 917-929. https://doi.org/10.1177/0956797619844269

Barlow, F. K., Hornsey, M. J., Thai, M., Sengupta, N. K., \& Sibley, C. G. (2013). The wallpaper effect: The contact hypothesis fails for minority group members who live in areas with a high proportion of majority group members. PLoS One, 8(12), e82228. https://doi.org/10.1371/journal.pone.0082228

Barlow, F. K., Louis, W. R., \& Hewstone, M. (2009). Rejected! Cognitions of rejection and intergroup anxiety as mediators of the impact of cross-group friendships on 
prejudice. British Journal of Social Psychology, 48(3), 389-405. https://doi.org/10.1348/014466608X387089

Bastian, B., Lusher, D., \& Ata, A. (2012). Contact, evaluation and social distance: Differentiating majority and minority effects. International Journal of Intercultural Relations, 36, 100-107. https://doi.org/10.1016/j.ijintrel.2011.02.005

Brooks, J. E., \& Neville, H. A. (2017). Interracial attraction among college men: the influence of ideologies, familiarity, and similarity. Journal of Social and Personal Relationships, 34(2), 166-183. https://doi.org/10.1177/0265407515627508

Callander, D., Newman, C. E., \& Holt, M. (2015). Is sexual racism really racism? Distinguishing attitudes toward sexual racism and generic racism among gay and bisexual men. Archives of Sexual Behavior, 44, 1991-2000. https://doi.org/10.1007/s10508-015-0487-3

Coley, N., Jacobson, S., Johanson, T.C., \& Kirby, S.A. (2009). Colors of love: Attitudes toward inter-ethnic romantic relationships among college students. Retrieved from https://wp.stolaf.edu/sociology/files/2013/06/The-Colors-of-Love.pdf

Collins, N. L., \& Miller, L. C. (1994). Self-disclosure and liking: A meta-analytic review. Psychological Bulletin, 116(3), 457-475. https://doi.org/10.1037/0033-2909.116.3.457

Davies, K., Tropp, L. R., Aron, A., Pettigrew, T. F., \& Wright, S. C. (2011). Cross-group friendships and intergroup attitudes: A meta-analytic review. Personality and Social Psychology Review, 15, 332-351. https://doi.org/10.1177/1088868311411103

Davies, K., Wright, S. C., Aron, A., \& Comeau, J. (2013). Intergroup contact through friendship: Intimacy and norms. In G. Hodson \& M. Hewstone (Eds.), Advances in intergroup contact (p. 200-229). Psychology Press.

Dixon, J., Tredoux, C., Davies, G., Huck, J., Hocking, B., Sturgeon, B., Whyatt, D., Jarman, N., \& Bryan, D. (2020). Parallel lives: Intergroup contact, threat, and the segregation 
of everyday activity spaces. Journal of Personality and Social Psychology, 118(3), 457-480. https://doi.org/10.1037/pspi0000191

Eastwick, P. W., Finkel, E. J., Mochon, D., \& Ariely, D. (2007). Selective versus unselective romantic desire: Not all reciprocity is created equal. Psychological Science, 18(4), 317-319. https://doi.org/10.1111/j.1467-9280.2007.01897.x

Emerson, M. O., Kimbro, R. T., \& Yancey, G. (2002). Contact theory extended: The effects of prior racial contact on current social ties. Social Science Quarterly, 83, 745-761. https://doi.org/10.1111/1540-6237.00112

Foeman, A., \& Nance, T. (2002). Building new cultures, reframing old images: Success strategies of interracial couples. Howard Journal of Communication, 13(3), 237-249. https://doi.org/10.1080/10646170290109716

Fujino, D. C. (1997). The rates, patterns and reasons for forming heterosexual interracial dating relationships among Asian Americans. Journal of Social and Personal Relationships, 14(6), 809-828. https://doi.org/10.1177/0265407597146006

Gaertner, S. L., Dovidio, J. F., \& Samuel, G. (2000). Reducing intergroup bias: The common ingroup identity model. Psychology Press.

Givens, D. B. (1978). The nonverbal basis of attraction: Flirtation, courtship, and seduction. Psychiatry, 41(4), 346-359. https://doi.org/10.1080/00332747.1978.11023994

Golash-Boza, T., \& Darity Jr, W. (2008). Latino racial choices: the effects of skin colour and discrimination on Latinos' and Latinas' racial self-identifications. Ethnic and Racial Studies, 31(5), 899-934. https://doi.org/10.1080/01419870701568858

Han, C. S. (2007). They don't want to cruise your type: Gay men of color and the racial politics of exclusion. Social Identities, 13, 51-67. https://doi.org/10.1080/13504630601163379 
Harwood, J. (2010). The contact space: A novel framework for intergroup contact research. Journal of Language and Social Psychology, 29(2), 147-177. https://doi.org/10.1177/0261927X09359520

Hayes, A. F. (2009). Beyond Baron and Kenny: Statistical mediation analysis in the new millennium. Communication Monographs, 76, 408-420. https://doi.org/10.1080/03637750903310360

Hayward, L. E., Tropp, L. R., Hornsey, M. J., \& Barlow, F. K. (2017). Toward a comprehensive understanding of intergroup contact: Descriptions and mediators of positive and negative contact among majority and minority groups. Personality and Social Psychology Bulletin, 43(3), 347-364. https://doi.org/10.1177/0146167216685291

Henderson-King, E., Henderson-King, D., Zhermer, N., Posokhova, S., \& Chiker, V. (1997). In-group favoritism and perceived similarity: A look at Russians' perceptions in the post-Soviet era. Personality and Social Psychology Bulletin, 23(10), 1013-1021. https://doi.org/10.1177/01461672972310002

Herman, M. R., \& Campbell, M. E. (2012). I wouldn't, but you can: Attitudes toward interracial relationships. Social Science Research, 41, 343-358. https://doi.org/10.1016/j.ssresearch.2011.11.007

Hinde, R. A. (Ed.). (1972). Non-verbal communication. Cambridge University Press. Ho, A. K., Sidanius, J., Kteily, N., Sheehy-Skeffington, J., Pratto, F., Henkel, K. E., ... \& Stewart, A. L. (2015). The nature of social dominance orientation: Theorizing and measuring preferences for intergroup inequality using the new $\mathrm{SDO}_{7}$ scale. Journal of Personality and Social Psychology, 109(6), 1003-1028. https://doi.org/10.1037/pspi0000033 
Ioannou, M., \& Panagiotou, E. (in press). Opening the black box of contact: Unravelling the ways through which positive contact is imagined in a post-conflict context. Journal of Community \& Applied Social Psychology. Advance online publication. https://doi.org/10.1002/casp.2465

Johnson, B. R., \& Jacobson, C. K. (2005). Contact in context: An examination of social settings on whites' attitudes toward interracial marriage. Social Psychology Quarterly, 68, 387-399. https://doi.org/10.1177/019027250506800406

Keil, T. F., \& Koschate, M. (2020). Variations in subjective definitions of everyday situations as intergroup contact. British Journal of Social Psychology, 59(4), 965-991. Advance online publication. https://doi.org/10.1111/bjso.12372

Lalonde, R. N., Giguère, B., Fontaine, M., \& Smith, A. (2007). Social dominance orientation and ideological asymmetry in relation to interracial dating and transracial adoption in Canada. Journal of Cross-Cultural Psychology, 38, 559-572. https://doi.org/10.1177/0022022107305238

Laurenceau, J.-P., Barrett, L. F., \& Pietromonaco, P. R. (1998). Intimacy as an interpersonal process: The importance of self-disclosure, partner disclosure, and perceived partner responsiveness in interpersonal exchanges. Journal of Personality and Social Psychology, 74(5), 1238-1251. https://doi.org/10.1037/0022-3514.74.5.1238

Levin, S., Taylor, P. L., \& Caudle, E. (2007). Interethnic and interracial dating in college: A longitudinal study. Journal of Social and Personal Relationships, 24, 323-341. https://doi.org/10.1177/0265407507077225

Levin, S., Van Laar, C., \& Sidanius, J. (2003). The effects of ingroup and outgroup friendships on ethnic attitudes in college: A longitudinal study. Group Processes \& Intergroup Relations, 6, 76-92. https://doi.org/10.1177/1368430203006001013 
Lewis, K. (2013). The limits of racial prejudice. Proceedings of the National Academy of Sciences, 110(47), 18814-18819. https://doi.org/10.1073/pnas.1308501110

Lindell, M. K., \& Whitney, D. J. (2001). Accounting for common method variance in crosssectional research designs. Journal of Applied Psychology, 86(1), 114-121. https://doi.org/10.1037/0021-9010.86.1.114

Liu, J. H., Campbell, S. M., \& Condie, H. (1995). Ethnocentrism in dating preferences for an American sample: The ingroup bias in social context. European Journal of Social Psychology, 25(1), 95-115. https://doi.org/10.1002/ejsp.2420250108

Marinucci, M., Maunder, R., Sanchez, K., Thai, M., McKeown, S., Turner, R. N., \& Stevenson, C. (2021). Intimate intergroup contact across the lifespan. Journal of Social Issues, 77(1), 64-85. https://doi.org/10.1111/josi.12399

Monsour, M. (1992). Meanings of intimacy in cross-and same-sex friendships. Journal of Social and Personal Relationships, 9(2), 277-295. https://doi.org/10.1177/0265407592092007

Muthén, L. K. and Muthén, B. O. (2017). Mplus User's Guide. Eighth Edition. Los Angeles, CA: Muthén \& Muthén

Paterson, J. L., Turner, R. N., \& Conner, M. T. (2015). Extended contact through cross-group romantic relationships. Journal of Applied Social Psychology, 45(9), 489-497. https://doi.org/10.1111/jasp.12314

Paterson, J. L., Turner, R. N., \& Hodson, G. (2019). Receptivity to dating and marriage across the religious divide in Northern Ireland: The role of intergroup contact. Journal of Applied Social Psychology, 49(9), 575-584. https://doi.org/10.1111/jasp.12617

Peer, E., Brandimarte, L., Samat, S., \& Acquisti, A. (2017). Beyond the Turk: Alternative platforms for crowdsourcing behavioral research. Journal of Experimental Social Psychology, 70, 153-163. https://doi.org/10.1016/j.jesp.2017.01.006 
Pettigrew, T. F. (2008). Future directions for intergroup contact theory and research. International Journal of Intercultural Relations, 32, 187-199. https://doi.org/10.1016/j.ijintrel.2007.12.002

Pettigrew, T. F. (2009). Secondary transfer effect of contact: Do intergroup contact effects spread to non-contacted outgroups? Social Psychology, 40, 55-65. https://doi.org/10.1027/1864-9335.40.2.55

Pettigrew, T. F., \& Tropp, L. R. (2006). A meta-analytic test of intergroup contact theory. Journal of Personality and Social Psychology, 90, 751-783. https://doi.org/10.1037/0022-3514.90.5.751

Pettigrew, T. F., \& Tropp, L. R. (2008). How does intergroup contact reduce prejudice? Meta-analytic tests of three mediators. European Journal of Social Psychology, 38(6), 922-934. https://doi.org/10.1002/ejsp.504

Olson, M. A., Johnson, C. S., Zabel, K. L., \& Phillips, J. E. (2018). Different sides of the same conversation: Black and White partners differ in perceptions of interaction content. Journal of Applied Social Psychology, 48(8), 424-436. https://doi.org/10.1111/jasp.12522

Reis, H. T., \& Shaver, P. (1988). Intimacy as an interpersonal process. Handbook of personal relationships. Routledge.

Roman, E. (2000). Who exactly is living La Vida Loca: The legal and political consequences of Latino-Latina ethnic and racial stereotypes in film and other media. Journal of Gender, Race and Justice., 4, 37-68.

Shelton, J. N., Trail, T. E., West, T. V., \& Bergsieker, H. B. (2010). From strangers to friends: The interpersonal process model of intimacy in developing interracial friendships. Journal of Social and Personal Relationships, 27(1), 71-90. https://doi.org/10.1177/0265407509346422 
Singer, B. (1984). Conceptualizing sexual arousal and attraction. Journal of Sex Research, 20(3), 230-240. https://doi.org/10.1080/00224498409551222

Sprecher, S., Treger, S., Wondra, J. D., Hilaire, N., \& Wallpe, K. (2013). Taking turns: Reciprocal self-disclosure promotes liking in initial interactions. Journal of Experimental Social Psychology, 49(5), 860-866. https://doi.org/10.1016/j.jesp.2013.03.017

Tam, T., Hewstone, M., Harwood, J., Voci, A., \& Kenworthy, J. (2006). Intergroup contact and grandparent-grandchild communication: The effects of self-disclosure on implicit and explicit biases against older people. Group Processes \& Intergroup Relations, 9(3), 413-429. https://doi.org/10.1177/1368430206064642

Tam, T., Hewstone, M., Kenworthy, J., \& Cairns, E. (2009). Intergroup trust in Northern Ireland. Personality and Social Psychology Bulletin, 35(1), 45-59. https://doi.org/10.1177/0146167208325004

Techakesari, P., Barlow, F. K., Hornsey, M. J., Sung, B., Thai, M., \& Chak, J. L. (2015). An investigation of positive and negative contact as predictors of intergroup attitudes in the United States, Hong Kong, and Thailand. Journal of Cross-Cultural Psychology, 46(3), 454-468. https://doi.org/10.1177/0022022115570313

Thai, M. (2020). Sexual racism is associated with lower self-esteem and life satisfaction in men who have sex with men. Archives of Sexual Behavior, 49(1), 347-353. https://doi.org/10.1007/s10508-019-1456-Z

Thai, M., Stainer, M. J., \& Barlow, F. K. (2019). The "preference" paradox: Disclosing racial preferences in attraction is considered racist even by people who overtly claim it is not. Journal of Experimental Social Psychology, 83, 70-77. https://doi.org/10.1016/j.jesp.2019.03.004 
Tidwell, N. D., Eastwick, P. W., \& Finkel, E. J. (2013). Perceived, not actual, similarity predicts initial attraction in a live romantic context: Evidence from the speed-dating paradigm. Personal Relationships, 20(2), 199-215. https://doi.org/10.1111/j.14756811.2012.01405.x

Tropp, L. R., \& Pettigrew, T. F. (2005). Relationships between intergroup contact and prejudice among minority and majority status groups. Psychological Science, 16(12), 951-957. https://doi.org/10.1111/j.1467-9280.2005.01643.x

Tropp, L. R., Stout, A. M., Boatswain, C., Wright, S. C., \& Pettigrew, T. F. (2006). Trust and acceptance in response to references to group membership: Minority and majority perspectives on cross-group interactions. Journal of Applied Social Psychology, 36(3), 769-794. https://doi.org/10.1111/j.0021-9029.2006.00031.x

Turner, R. N., \& Feddes, A. R. (2011). How intergroup friendship works: A longitudinal study of friendship effects on outgroup attitudes. European Journal of Social Psychology, 41(7), 914-923. https://doi.org/10.1002/ejsp.843

Turner, R. N., Hewstone, M., \& Voci, A. (2007). Reducing explicit and implicit outgroup prejudice via direct and extended contact: The mediating role of self-disclosure and intergroup anxiety. Journal of Personality and Social Psychology, 93, 369-388. https://doi.org/10.1037/0022-3514.93.3.369

Turner, R. N., Hewstone, M., Voci, A., \& Vonofakou, C. (2008). A test of the extended intergroup contact hypothesis: The mediating role of intergroup anxiety, perceived ingroup and outgroup norms, and inclusion of the outgroup in the self. Journal of Personality and Social Psychology, 95(4), 843-860. https://doi.org/10.1037/a0011434

Wilkins, C. L., Chan, J. F., \& Kaiser, C. R. (2011). Racial stereotypes and interracial attraction: Phenotypic prototypicality and perceived attractiveness of Asians. Cultural 
Diversity and Ethnic Minority Psychology, 17, 427-431.

https://doi.org/10.1037/a0024733

Wright, S. C., \& Tropp, L. R. (2005). Language and intergroup contact: Investigating the impact of bilingual instruction on children's intergroup attitudes. Group Processes \& Intergroup Relations, 8(3), 309-328. https://doi.org/10.1177/1368430205053945 


\section{Table 1}

Means, standard deviations, and bivariate correlations between all variables in Study $1(N=240)$.

\begin{tabular}{|c|c|c|c|c|c|c|c|c|c|c|c|c|c|c|c|c|c|c|}
\hline & $M(S D)$ & $\alpha$ & 1 & 2 & 3 & 4 & 5 & 6 & 7 & 8 & 9 & 10 & 11 & 12 & 13 & 14 & 15 & 16 \\
\hline 1. Black friendships & $2.01(0.84)$ & .78 & - & & & & & & & & & & & & & & & \\
\hline $\begin{array}{l}\text { 3. South Asian } \\
\text { friendships }\end{array}$ & $1.82(0.72)$ & .77 & $.37^{* * * *}$ & $.40^{* * * *}$ & - & & & & & & & & & & & & & \\
\hline 4. Latinx friendships & $1.69(0.74)$ & .77 & $.40^{* * *}$ & $.17^{* *}$ & $.38^{* * * *}$ & - & & & & & & & & & & & & \\
\hline $\begin{array}{l}\text { 5. Middle-Eastern } \\
\text { friendships }\end{array}$ & $1.67(0.75)$ & .76 & $.34^{* * * *}$ & $.23^{* * * *}$ & $.40^{* * * *}$ & $.45^{* * * *}$ & - & & & & & & & & & & & \\
\hline $\begin{array}{l}\text { 6. Indigenous } \\
\text { friendships }\end{array}$ & $1.98(0.90)$ & .81 & $.40^{* * *}$ & $.23^{* * * *}$ & .09 & $.23^{* * *}$ & $.29^{* * * *}$ & - & & & & & & & & & & \\
\hline 7. Black attraction & $4.83(1.53)$ & .97 & $.26^{* * *}$ & .05 & .10 & .07 & .11 & $.14^{*}$ & - & & & & & & & & & \\
\hline 8. Asian attraction & $4.52(1.55)$ & .97 & .12 & $.21^{* *}$ & .12 & .01 & .08 & .06 & $.57^{* * *}$ & - & & & & & & & & \\
\hline $\begin{array}{l}\text { 9. South Asian } \\
\text { attraction }\end{array}$ & $4.02(1.53)$ & .96 & $.16^{*}$ & .12 & $.24^{* * *}$ & .03 & $.14^{*}$ & .03 & $.63^{* * *}$ & $.74^{* * *}$ & - & & & & & & & \\
\hline 10. Latinx attraction & $5.32(1.26)$ & .96 & .07 & .03 & .01 & $.17^{* *}$ & .06 & .08 & $.61^{* * *}$ & $.54^{* * *}$ & $.51^{* * *}$ & - & & & & & & \\
\hline $\begin{array}{l}\text { 11. Middle-Eastern } \\
\text { attraction }\end{array}$ & $4.40(1.47)$ & .96 & $.15^{*}$ & .07 & $.16^{*}$ & .09 & $.26^{* * *}$ & .05 & $.67^{* * *}$ & $.64^{* * * *}$ & $.75^{* * * *}$ & $.69^{* * * *}$ & - & & & & & \\
\hline $\begin{array}{l}\text { 12. Indigenous } \\
\text { attraction }\end{array}$ & $4.40(1.58)$ & .97 & $.18^{* *}$ & .06 & .09 & .05 & .12 & $.27^{* * * *}$ & $.69^{* * *}$ & $.49^{* * * *}$ & $.64^{* * * *}$ & $.56^{* * * *}$ & $.66^{* * * *}$ & - & & & & \\
\hline 13. White friendships & $4.13(0.72)$ & .72 & .00 & .01 & .11 & -.06 & -.05 & .12 & .09 & -.05 & -.04 & .13 & .04 & .04 & - & & & \\
\hline 14. Gender ${ }^{\mathrm{a}}$ & - & - & .04 & -.04 & .03 & .01 & .08 & .07 & .06 & $-.21 * *$ & $-.14 *$ & -.08 & $-.12 *$ & .08 & .02 & - & & \\
\hline 15. Sexual Orientation ${ }^{\mathrm{b}}$ & - & - & .01 & -.01 & .02 & -.05 & -.04 & -.03 & -.06 & .01 & -.01 & .01 & -.01 & -.01 & .05 & .01 & - & \\
\hline 14. SDO & $4.02(0.54)$ & .96 & .06 & .04 & .02 & .02 & -.06 & -.08 & $-.16^{*}$ & -.08 & -.04 & -.11 & -.10 & $-.16^{*}$ & .02 & -.03 & -.09 & - \\
\hline
\end{tabular}


${ }^{*} p<.05, * * p<.01, * * * p<.001 ;{ }^{\mathrm{a}} 1=$ Female, $0=$ Male and Non-Binary, ${ }^{\mathrm{b}} 1=$ Heterosexual, $0=$ Other 
Table 2

Cross-race friendships and covariates as predictors of attraction in Study $1(N=240)$.

\begin{tabular}{|c|c|c|c|c|c|c|c|c|c|c|c|c|}
\hline \multirow[b]{2}{*}{ Friendships } & \multicolumn{2}{|c|}{$\begin{array}{c}\text { Black } \\
\text { Attraction }\end{array}$} & \multicolumn{2}{|c|}{$\begin{array}{c}\text { Asian } \\
\text { Attraction }\end{array}$} & \multicolumn{2}{|c|}{$\begin{array}{c}\text { South Asian } \\
\text { Attraction }\end{array}$} & \multicolumn{2}{|c|}{$\begin{array}{c}\text { Latinx } \\
\text { Attraction }\end{array}$} & \multicolumn{2}{|c|}{$\begin{array}{l}\text { Middle-Eastern } \\
\text { Attraction }\end{array}$} & \multicolumn{2}{|c|}{$\begin{array}{c}\text { Indigenous } \\
\text { Attraction }\end{array}$} \\
\hline & $\beta(\mathrm{SE})$ & $p$ & $\beta(\mathrm{SE})$ & $p$ & $\beta(\mathrm{SE})$ & $p$ & $\beta(\mathrm{SE})$ & $p$ & $\beta(\mathrm{SE})$ & $p$ & $\beta(\mathrm{SE})$ & $p$ \\
\hline Black & $.27(.07)$ & $<.001$ & $.08(.07)$ & .259 & $.11(.08)$ & .135 & $.02(.08)$ & .796 & $.11(.07)$ & .146 & $.12(.07)$ & .119 \\
\hline Asian & $-.05(.07)$ & .472 & $.18(.07)$ & .007 & $.01(.07)$ & .956 & $.01(.07)$ & .880 & $-.02(.07)$ & .775 & $-.04(.07)$ & .607 \\
\hline South Asian & $.05(.08)$ & .531 & $.03(.08)$ & .672 & $.22(.07)$ & .003 & $-.06(.08)$ & .428 & $.06(.08)$ & .391 & $.07(.08)$ & .361 \\
\hline Latinx & $-.05(.07)$ & .535 & $-.08(.07)$ & .267 & $-.14(.07)$ & .063 & $.20(.07)$ & .007 & $-.07(.07)$ & .333 & $-.07(.07)$ & .324 \\
\hline Middle-Eastern & $.01(.07)$ & .889 & $.04(.07)$ & .598 & $.08(.07)$ & .258 & $-.01(.07)$ & .864 & .25 (.07) & $<.001$ & $.01(.07)$ & .854 \\
\hline Indigenous & $.02(.07)$ & .739 & $-.003(.07)$ & .969 & $-.02(.07)$ & .767 & $.02(.07)$ & .806 & $-.06(.07)$ & .425 & $.22(.07)$ & .002 \\
\hline White & $.09(.06)$ & .138 & $-.04(.06)$ & .534 & $-.01(.06)$ & .258 & $.14(.06)$ & .024 & $.07(.06)$ & .253 & $.01(.06)$ & .831 \\
\hline SDO & $-.17(.06)$ & .004 & $-.11(.06)$ & .075 & $-0.06(.06)$ & .767 & $-0.13(06)$ & .042 & $-.11(.06)$ & .075 & $-.14(.06)$ & .022 \\
\hline Gender & $.05(.06)$ & .377 & $-.24(.06)$ & $<.001$ & $-.14(.06)$ & .025 & $-.14(.06)$ & .028 & $-.14(.06)$ & .018 & $.09(.06)$ & .146 \\
\hline $\begin{array}{l}\text { Sexual } \\
\text { Orientation }\end{array}$ & $-.06(.06)$ & .310 & $-.05(.06)$ & .466 & $-.03(.06)$ & .684 & $-.01(.06)$ & .924 & $-.03(.06)$ & .622 & $-.01(.06)$ & .918 \\
\hline
\end{tabular}




\section{Table 3}

Means, standard deviations, and bivariate correlations between all variables in Study $2 a(N=300)$.

\begin{tabular}{|c|c|c|c|c|c|c|c|c|c|c|c|c|c|c|c|c|}
\hline & $M(S D)$ & $\alpha$ & 1 & 2 & 3 & 4 & 5 & 6 & 7 & 8 & 9 & 10 & 11 & 12 & 13 & 14 \\
\hline 1. Friendships & $2.13(0.83)$ & .84 & - & & & & & & & & & & & & & \\
\hline $\begin{array}{l}\text { 2. Ingroup dating } \\
\text { norms }\end{array}$ & $4.61(1.35)$ & .75 & $.29^{* * * *}$ & - & & & & & & & & & & & & \\
\hline 3. Intergroup anxiety & $2.11(1.10)$ & .90 & $-.35^{* * *}$ &.$- .30^{* * *}$ & - & & & & & & & & & & & \\
\hline $\begin{array}{l}\text { 4. Intergroup } \\
\text { empathy }\end{array}$ & $4.98(1.20)$ & .94 & $.20^{* *}$ & $.26^{* * *}$ & $-.29^{* * * *}$ & - & & & & & & & & & & \\
\hline 5. Intergroup trust & $5.59(1.35)$ & .97 & $.32^{* * *}$ & $.31^{* * * *}$ & $-.56^{* * * *}$ & $.49^{* * * *}$ & - & & & & & & & & & \\
\hline $\begin{array}{l}\text { 6. Perceived } \\
\text { similarity }\end{array}$ & $4.24(1.34)$ & .90 & $.23^{* * *}$ & $.27^{* * * *}$ & $-.46^{* * *}$ & $.35^{* * * *}$ & $.58^{* * *}$ & - & & & & & & & & \\
\hline $\begin{array}{l}\text { 7. Perceived } \\
\text { reciprocity }\end{array}$ & $4.21(1.51)$ & .98 & $.39^{* * * *}$ & $.39^{* * * *}$ & $-.45^{* * * *}$ & $.26^{* * * *}$ & $.37^{* * *}$ & $.42^{* * * *}$ & - & & & & & & & \\
\hline 8. Self-disclosure & $2.85(1.52)$ & .97 & $.72^{* * *}$ & $.28^{* * *}$ & $-.36^{* * * *}$ &. $\mathbf{3 3}^{* * * *}$ & $.35^{* * *}$ & $.36^{* * * *}$ & $.44^{* * *}$ & - & & & & & & \\
\hline $\begin{array}{l}\text { 9. Non-verbal } \\
\text { intimacy }\end{array}$ & $3.77(1.39)$ & .90 & $.67^{* * * *}$ & $.32^{* * *}$ & $-.48^{* * *}$ & $.36 * *$ & $.48^{* * *}$ & $.48^{* * *}$ & $.50^{* * * *}$ & $.73^{* * *}$ & - & & & & & \\
\hline $\begin{array}{l}\text { 10. Intergroup } \\
\text { warmth }\end{array}$ & $\begin{array}{l}74.62 \\
(20.02)\end{array}$ & - & $.37^{* * *}$ & $.37^{* * * *}$ & $-.52^{* * * *}$ & $.53^{* * *}$ & $.64^{* * *}$ & $.55^{* * * *}$ & $.42^{* * * *}$ & $.39^{* * * *}$ & $.54^{* * *}$ & - & & & & \\
\hline $\begin{array}{l}\text { 11. Past romantic } \\
\text { engagement }\end{array}$ & $1.71(1.18)$ & - & $.39^{* * * *}$ & $.14^{*}$ & $-.12^{*}$ & .05 & .07 & $.13^{*}$ & $.37^{* * * *}$ & $.35^{* * * *}$ & $.35^{* * * *}$ & $.15^{*}$ & - & & & \\
\hline 12. Gender ${ }^{\mathrm{a}}$ & - & - & .02 & .02 & -.10 & $.27 * * *$ & $.18^{*}$ & .09 & .10 & $.22 * *$ & $.17 *$ & $.29 * *$ & -.01 & - & & \\
\hline $\begin{array}{l}\text { 13. Sexual } \\
\text { Orientation }^{\mathrm{b}}\end{array}$ & - & - & .02 & .09 & -.09 & $.21 * * *$ & $.17^{* *}$ & $.20 * * *$ & $.13^{*}$ & $.15^{* * *}$ & $.12^{*}$ & $.20 * *$ & .02 & $.24 * *$ & - & \\
\hline 14. Attraction & $4.89(1.32)$ & .95 & $.40^{* * * *}$ & $.48^{* * * *}$ & $-.35^{\text {**** }}$ & $.37^{* * * *}$ & $.50^{* * * *}$ & $.43^{* * * *}$ & $.55^{* * * *}$ & $.41^{* * * *}$ & $.45^{* * *}$ & $.57^{* * * * *}$ & $.39^{* * * *}$ & .07 & $.18^{* *}$ & - \\
\hline
\end{tabular}

${ }^{*} p<.05, * * p<.01,{ }^{* * *} p<.001 ;{ }^{\mathrm{a}} 1=$ Female, $0=$ Male and Non-Binary, ${ }^{\mathrm{b}} 1=$ Heterosexual, $0=$ Other 


\section{Table 4}

Means, standard deviations, and bivariate correlations between all variables in Study $2 b(N=303$; White British participants).

\begin{tabular}{|c|c|c|c|c|c|c|c|c|c|c|c|c|c|c|c|}
\hline & $M(S D)$ & $\alpha$ & 1 & 2 & 3 & 4 & 5 & 6 & 7 & 8 & 9 & 10 & 11 & 12 & 13 \\
\hline 1. Friendships & $1.90(0.82)$ & .88 & - & & & & & & & & & & & & \\
\hline $\begin{array}{l}\text { 2. Ingroup dating } \\
\text { norms }\end{array}$ & $4.79(1.33)$ & .84 & $.22^{* * *}$ & - & & & & & & & & & & & \\
\hline 3. Intergroup anxiety & $1.74(0.92)$ & .83 & $-.18^{* *}$ &.$- .33^{* * * *}$ & - & & & & & & & & & & \\
\hline $\begin{array}{l}\text { 4. Intergroup } \\
\text { empathy }\end{array}$ & $3.01(1.09)$ & .92 & $.27^{* * * *}$ & $.20^{* * * *}$ & $-.13^{*}$ & - & & & & & & & & & \\
\hline 5. Intergroup trust & $5.65(1.19)$ & .92 & $.19^{* *}$ & $.39^{* * * *}$ & $-.42^{* * *}$ & $.36^{* * *}$ & - & & & & & & & & \\
\hline $\begin{array}{l}\text { 6. Perceived } \\
\text { similarity }\end{array}$ & $4.82(1.30)$ & .92 & $.25^{* * *}$ & $.42^{* * * *}$ & $-.36^{* * *}$ & $.32^{* * *}$ & $.41^{* * * *}$ & - & & & & & & & \\
\hline $\begin{array}{l}\text { 7. Perceived } \\
\text { reciprocity }\end{array}$ & $4.33(1.41)$ & .98 & $.30^{* * * *}$ & $.44^{* * * *}$ & $-.36^{* * *}$ & $.12^{*}$ & $.24^{* * *}$ & $.34^{* * * *}$ & - & & & & & & \\
\hline 8. Self-disclosure & $2.66(1.68)$ & .98 & $.78^{* * *}$ & $.25^{* * * *}$ & $-.19^{* *}$ & $.32^{* * *}$ & $.24^{* * *}$ & $.32^{* * *}$ & $.28^{* * *}$ & - & & & & & \\
\hline $\begin{array}{l}\text { 9. Non-verbal } \\
\text { intimacy }\end{array}$ & $3.77(1.50)$ & .91 & $.72^{* * *}$ & $.27^{* * *}$ & $-.33^{* * *}$ & $.34^{* * *}$ & $.34^{* * *}$ & $.35^{* * *}$ & $.43^{* * *}$ & $.78^{* * *}$ & - & & & & \\
\hline 10. Intergroup warmth & $\begin{array}{c}77.35 \\
(19.21)\end{array}$ & - & $.27^{* * *}$ & $.45^{* * * *}$ & $-.45^{* * *}$ & $.39^{* * *}$ & $.56 * * *$ & $.46^{* * *}$ & $.40^{* * * *}$ & $.28^{* * *}$ & $.45^{* * * *}$ & - & & & \\
\hline $\begin{array}{l}\text { 11. Past romantic } \\
\text { engagement }\end{array}$ & $1.58(1.05)$ & - & $.35^{* * *}$ & .07 & $-.14^{*}$ & .06 & .01 & .09 & $.24^{* * *}$ & $.35^{* * * *}$ & $.29^{* * * * *}$ & .10 & - & & \\
\hline 12. Gender ${ }^{\mathrm{a}}$ & - & - & .05 & .03 & -.05 & $.15^{*}$ & .09 & .06 & .02 & .10 & $.16^{*}$ & .08 & .05 & - & \\
\hline $\begin{array}{l}\text { 13. Sexual } \\
\text { Orientation }^{\mathrm{b}}\end{array}$ & - & - & -.03 & -.06 & -.02 & -.09 & -.01 & -.01 & -.09 & -.06 & -.06 & -.01 & .04 & -.05 & - \\
\hline 14. Attraction & $4.93(1.39)$ & .97 & $.32^{* * *}$ & $.55^{* * * *}$ & $-.35^{* * * *}$ & $.26^{* * * *}$ & $.33^{* * * *}$ & $.42^{* * * *}$ & $.50^{* * * *}$ & $.33^{* * *}$ & $.37^{* * * *}$ & $.52^{* * * *}$ & $.29^{* * * *}$ & -.06 & $-.15^{*}$ \\
\hline
\end{tabular}

${ }^{*} p<.05, * * p<.01,{ }^{* * *} p<.001 ;{ }^{\mathrm{a}} 1=$ Female, $0=$ Male and Non-Binary, ${ }^{\mathrm{b}} 1=$ Heterosexual, $0=$ Other 


\section{Table 5}

Standardized regression coefficients for each of the pathways tested in Studies $2 a, 2 b$, and 3.

\begin{tabular}{|c|c|c|c|}
\hline Direct pathways & Study 2a & Study $2 b$ & Study 3 \\
\hline \multicolumn{4}{|l|}{ Cross-Race Friendships $\rightarrow$} \\
\hline Perceived Ingroup Dating Norms & $.30(.06), p<.001$ & $.21(.05), p<.001$ & $.35(.06), p<.001$ \\
\hline Self-Disclosure & $.72(.03), p<.001$ & $.78(.03), p<.001$ & $.58(.04), p<.001$ \\
\hline Non-Verbal Intimacy & $.67(.03), p<.001$ & $.72(.03), p<.001$ & $.49(.04), p<.001$ \\
\hline \multicolumn{4}{|l|}{ Perceived Ingroup Dating Norms $\rightarrow$} \\
\hline Warmth & $.10(.05), p=.013$ & $.13(.05), p=.012$ & $.07(.06), p=.224$ \\
\hline Attraction & $.20(.05), p<.001$ & $.29(.05), p<.001$ & $.26(.05), p<.001$ \\
\hline \multicolumn{4}{|l|}{ Self-Disclosure $\rightarrow$} \\
\hline Anxiety & $-.03(.06), p=.645$ & $.17(.08), p=.024$ & $-.06(.08), p=.457$ \\
\hline Empathy & $.15(.08), p=.051$ & $.15(.09), p=.095$ & $.22(.07), p=.001$ \\
\hline Trust & $.01(.08), p=.901$ & $-.07(.09), p=.431$ & $.35(.06), p<.001$ \\
\hline Perceived Similarity & $.04(.09), p=.656$ & $.10(.07), p=.145$ & $.33(.07), p<.001$ \\
\hline Perceived Reciprocity & $.18(.08), p=.033$ & $-.13(.08), p=.112$ & $.28(.07), p<.001$ \\
\hline \multicolumn{4}{|l|}{ Non-Verbal Intimacy $\rightarrow$} \\
\hline Anxiety & $-.44(.07), p<.001$ & $-.43(.08), p<.001$ & $-.42(.08), p<.001$ \\
\hline Empathy & $.23(.08), p=.004$ & $.21(.09), p=.021$ & $.13(.07), p=.066$ \\
\hline Trust & $.45(.08), p<.001$ & $.36(.10), p<.001$ & $.21(.07), p=.001$ \\
\hline Perceived Similarity & $.43(.08), p<.001$ & $.24(.08), p=.002$ & $.20(.07), p=.002$ \\
\hline Perceived Reciprocity & $.35(.09), p<.001$ & $.50(.08), p<.001$ & $.21(.07), p=.003$ \\
\hline \multicolumn{4}{|l|}{ Anxiety $\rightarrow$} \\
\hline Warmth & $-.16(.06), p=.013$ & $-.17(.06), p=.003$ & $-.15(.06), p=.008$ \\
\hline Attraction & $.12(.06), p=.030$ & $-.02(.06), p=.657$ & $.03(.05), p=.545$ \\
\hline \multicolumn{4}{|l|}{ Empathy $\rightarrow$} \\
\hline Warmth & $.24(.06), p<.001$ & $.19(.05), p<.001$ & $.23(.05), p<.001$ \\
\hline Attraction & $.04(.05), p=.508$ & $.05(.05), p=.343$ & $.03(.05), p=.489$ \\
\hline \multicolumn{4}{|l|}{ Trust $\rightarrow$} \\
\hline Warmth & $.28(.07), p<.001$ & $.29(.06), p<.001$ & $.32(.07), p<.001$ \\
\hline Attraction & $.21(.07), p=.004$ & $-.03(.06), p=.579$ & $.13(.06), p=.026$ \\
\hline \multicolumn{4}{|l|}{ Perceived Similarity $\rightarrow$} \\
\hline Warmth & $.17(.06), p=.001$ & $.11(.06), p=.071$ & $.01(.06), p=.966$ \\
\hline Attraction & $.01(.06), p=.840$ & $.11(.06), p=.053$ & $.08(.05), p=.147$ \\
\hline \multicolumn{4}{|l|}{ Perceived Reciprocity $\rightarrow$} \\
\hline Warmth & $.07(.05), p=.181$ & $.15(.05), p=.002$ & $.11(.06), p=.053$ \\
\hline Attraction & $.24(.06), p<.001$ & $.17(.06), p=.007$ & $.21(.05), p<.001$ \\
\hline \multicolumn{4}{|l|}{ Warmth $\rightarrow$} \\
\hline Attraction & $.28(.07), p<.001$ & $.25(.07), p=.001$ & $.25(.06), p<.001$ \\
\hline
\end{tabular}


Study 2a: $\chi^{2}(40)=135.18, p<.001$, CFI $=.94$, TLI $=.89$, RMSEA $=.09$, SRMR $=.08$

Study $2 \mathrm{~b}: \chi^{2}(40)=67.57, p=.004, \mathrm{CFI}=.98, \mathrm{TLI}=.96, \mathrm{RMSEA}=.05, \mathrm{SRMR}=.05$

Study 3: $\chi^{2}(40)=180.42, p<.001, \mathrm{CFI}=.90, \mathrm{TLI}=.78, \mathrm{RMSEA}=.11, \mathrm{SRMR}=.10$

Note. Standard errors associated with each regression coefficient are displayed in parentheses. 


\section{Table 6}

Unstandardized specific indirect effects running through non-verbal intimacy, self-disclosure, and perceived ingroup dating norms in Studies $2 a, 2 b$, and 3.

\begin{tabular}{|c|c|c|c|}
\hline Indirect effects & Study 2a & Study $2 b$ & Study 3 \\
\hline \multicolumn{4}{|c|}{ Cross-Race Friendship $\rightarrow$ Non-Verbal Intimacy $\rightarrow$} \\
\hline Anxiety $\rightarrow$ Attraction & $\begin{array}{c}-0.06 \\
{[-0.12,-0.01]}\end{array}$ & $\begin{array}{c}0.01 \\
{[-0.04,0.07]}\end{array}$ & $\begin{array}{c}-0.01 \\
{[-0.05,0.02]}\end{array}$ \\
\hline Anxiety $\rightarrow$ Warmth $\rightarrow$ Attraction & $\begin{array}{c}0.02 * \\
{[-0.01,0.05]}\end{array}$ & $\begin{array}{c}0.02 * \\
{[0.01,0.06]}\end{array}$ & $\begin{array}{c}0.01 * \\
{[0.003,0.03]}\end{array}$ \\
\hline Empathy $\rightarrow$ Attraction & $\begin{array}{c}0.01 \\
{[-0.02,0.04]}\end{array}$ & $\begin{array}{c}0.01 \\
{[-0.01,0.06]}\end{array}$ & $\begin{array}{c}0.003 \\
{[-0.01,0.02]}\end{array}$ \\
\hline Empathy $\rightarrow$ Warmth $\rightarrow$ Attraction & $\begin{array}{c}0.02 * \\
{[0.01,0.05]}\end{array}$ & $\begin{array}{c}0.01 * \\
{[0.002,0.03]}\end{array}$ & $\begin{array}{c}0.01 * \\
{[0.001,0.02]}\end{array}$ \\
\hline Trust $\rightarrow$ Attraction & $\begin{array}{c}0.10^{*} \\
{[0.04,0.18]}\end{array}$ & $\begin{array}{c}-0.01 \\
{[-0.07,0.03]}\end{array}$ & $\begin{array}{c}0.02 * \\
{[0.002,0.06]}\end{array}$ \\
\hline Trust $\rightarrow$ Warmth $\rightarrow$ Attraction & $\begin{array}{c}0.04 * \\
{[0.01,0.09]}\end{array}$ & $\begin{array}{c}\mathbf{0 . 0 3}^{*} \\
{[0.01,0.07]}\end{array}$ & $\begin{array}{c}0.01 * \\
{[0.01,0.04]}\end{array}$ \\
\hline Similarity $\rightarrow$ Attraction & $\begin{array}{c}0.01 \\
{[-0.05,0.06]}\end{array}$ & $\begin{array}{c}0.03 * \\
{[0.003,0.08]}\end{array}$ & $\begin{array}{c}0.01 \\
{[-0.002,0.04]}\end{array}$ \\
\hline Similarity $\rightarrow$ Warmth $\rightarrow$ Attraction & $\begin{array}{c}0.02 * \\
{[0.01,0.05]}\end{array}$ & $\begin{array}{c}0.01 * \\
{[0.001,0.03]}\end{array}$ & $\begin{array}{c}0.00 \\
{[-0.01,0.01]}\end{array}$ \\
\hline Reciprocity $\rightarrow$ Attraction & $\begin{array}{c}0.09 * \\
{[0.03,0.16]}\end{array}$ & $\begin{array}{c}0.10^{*} \\
{[0.04,0.2]}\end{array}$ & $\begin{array}{c}0.04 * \\
{[0.01,0.08]}\end{array}$ \\
\hline Reciprocity $\rightarrow$ Warmth $\rightarrow$ Attraction & $\begin{array}{c}0.01 \\
{[-0.002,0.03]}\end{array}$ & $\begin{array}{c}0.02^{*} \\
{[0.01,0.06}\end{array}$ & $\begin{array}{c}0.01 * \\
{[0.001,0.01]}\end{array}$ \\
\hline \multicolumn{4}{|l|}{ Cross-Race Friendship $\rightarrow$ Self-Disclosure $\rightarrow$} \\
\hline Anxiety $\rightarrow$ Attraction & $\begin{array}{c}-0.004 \\
{[-0.03,0.01]}\end{array}$ & $\begin{array}{c}-0.01 \\
{[-0.04,0.01]}\end{array}$ & $\begin{array}{c}-0.002 \\
{[-0.02,0.004]}\end{array}$ \\
\hline Anxiety $\rightarrow$ Warmth $\rightarrow$ Attraction & $\begin{array}{c}0.001 \\
{[-0.01,0.01]}\end{array}$ & $\begin{array}{c}-0.01 * \\
{[-0.04,-0.002]}\end{array}$ & $\begin{array}{c}0.002 \\
{[-0.003,0.01]}\end{array}$ \\
\hline Empathy $\rightarrow$ Attraction & $\begin{array}{c}0.01 \\
{[-0.01,0.04]}\end{array}$ & $\begin{array}{c}0.01 \\
{[-0.01,0.06]}\end{array}$ & $\begin{array}{c}0.01 \\
-0.01,0.03]\end{array}$ \\
\hline Empathy $\rightarrow$ Warmth $\rightarrow$ Attraction & $\begin{array}{c}0.01 * \\
{[0.002,0.03]}\end{array}$ & $\begin{array}{c}0.01 * \\
{[0.001,0.03]}\end{array}$ & $\begin{array}{c}0.01 * \\
{[0.01,0.03]}\end{array}$ \\
\hline Trust $\rightarrow$ Attraction & $\begin{array}{c}0.002 \\
{[-0.03,0.05]}\end{array}$ & $\begin{array}{c}0.003 \\
{[-0.01,0.03]}\end{array}$ & $\begin{array}{c}0.04 * \\
{[0.01,0.09]}\end{array}$ \\
\hline Trust $\rightarrow$ Warmth $\rightarrow$ Attraction & $\begin{array}{c}0.001 \\
{[-0.02,0.01]}\end{array}$ & $\begin{array}{c}-0.01 \\
{[-0.03,0.01]}\end{array}$ & $\begin{array}{c}0.03 * \\
{[0.01,0.05]}\end{array}$ \\
\hline Similarity $\rightarrow$ Attraction & $\begin{array}{c}0.001 \\
{[-0.01,0.02]}\end{array}$ & $\begin{array}{c}0.01 \\
{[-0.002,0.05]}\end{array}$ & $\begin{array}{c}0.02 \\
{[-0.01,0.06]}\end{array}$ \\
\hline Similarity $\rightarrow$ Warmth $\rightarrow$ Attraction & $\begin{array}{c}0.002 \\
{[-0.01,0.02]}\end{array}$ & $\begin{array}{c}0.004 * \\
{[0.001,0.02]}\end{array}$ & $\begin{array}{c}0.00 \\
{[-0.01,0.01]}\end{array}$ \\
\hline Reciprocity $\rightarrow$ Attraction & $\begin{array}{c}0.05^{*} \\
{[0.01,0.11]}\end{array}$ & $\begin{array}{c}-0.03 \\
{[-0.10,0.001]}\end{array}$ & $\begin{array}{c}0.05 * \\
{[0.02,0.10]}\end{array}$ \\
\hline Reciprocity $\rightarrow$ Warmth $\rightarrow$ Attraction & $\begin{array}{c}0.004 * \\
{[0.001,0.02]}\end{array}$ & $\begin{array}{c}-0.01 \\
{[-0.03,0.001]}\end{array}$ & $\begin{array}{c}0.01 * \\
{[0.001,0.02]}\end{array}$ \\
\hline \multicolumn{4}{|c|}{ Cross-Race Friendship $\rightarrow$ Ingroup Dating Norms $\rightarrow$} \\
\hline Attraction & $\begin{array}{c}0.09 * \\
{[0.04,0.17]}\end{array}$ & $\begin{array}{c}0.10 * \\
{[0.05,0.18]}\end{array}$ & $\begin{array}{c}0.15^{*} \\
{[0.08,0.24]}\end{array}$ \\
\hline Warmth $\rightarrow$ Attraction & $\begin{array}{c}0.01 * \\
{[0.003,0.04]}\end{array}$ & $\begin{array}{c}0.01 * \\
{[0.003,0.03]}\end{array}$ & $\begin{array}{c}0.01 \\
{[-0.004,0.03]}\end{array}$ \\
\hline
\end{tabular}


Note. Bias corrected, bootstrapped, $95 \%$ confidence intervals for each indirect effect are displayed in brackets. Indirect effects with confidence intervals that do not cross zero are statistically significant $(p<.05$, depicted with an asterisk in the table). 


\section{Table 7}

Means, standard deviations, and bivariate correlations between all variables in Study 3 ( $N=292$; Black British participants).

\begin{tabular}{|c|c|c|c|c|c|c|c|c|c|c|c|c|c|c|c|c|}
\hline & $M(S D)$ & $\alpha$ & 1 & 2 & 3 & 4 & 5 & 6 & 7 & 8 & 9 & 10 & 11 & 12 & 13 & 14 \\
\hline 1. Friendships & $2.78(0.96)$ & .86 & - & & & & & & & & & & & & & \\
\hline $\begin{array}{l}\text { 2. Ingroup dating } \\
\text { norms }\end{array}$ & $4.42(1.28)$ & .80 & $.39^{* * * *}$ & - & & & & & & & & & & & & \\
\hline 3. Intergroup anxiety & $2.35(1.20)$ & .84 & $-.34^{* * *}$ &.$- .34^{* * *}$ & - & & & & & & & & & & & \\
\hline $\begin{array}{l}\text { 4. Intergroup } \\
\text { empathy }\end{array}$ & $2.51(1.08)$ & .94 & $.25^{* * * *}$ & $.28^{* * * *}$ & $-.17^{* * *}$ & - & & & & & & & & & & \\
\hline 5. Intergroup trust & $4.18(1.46)$ & .95 & $.39^{* * * *}$ & $.41^{* * * *}$ & $-.45^{* * *}$ & $.50^{* * * *}$ & - & & & & & & & & & \\
\hline $\begin{array}{l}\text { 6. Perceived } \\
\text { similarity }\end{array}$ & $3.49(1.44)$ & .91 & $.40^{* * * *}$ & $.49^{* * * *}$ & $-.36^{* * * *}$ & $.34^{* * * *}$ & $.55^{* * *}$ & - & & & & & & & & \\
\hline $\begin{array}{l}\text { 7. Perceived } \\
\text { reciprocity }\end{array}$ & $4.48(1.67)$ & .95 & $.38^{* * *}$ & $.37^{* * * *}$ & $-.22^{* * * *}$ & $.13^{*}$ & $.28^{* * * *}$ & $.43^{* * *}$ & - & & & & & & & \\
\hline 8. Self-disclosure & $3.45(1.58)$ & .94 & $.57^{* * * *}$ & $.49^{* * * *}$ & $-.34^{* * * *}$ & $.33^{* * * *}$ & $.51^{* * * *}$ & $.51^{* * * *}$ & $.44^{* * * *}$ & - & & & & & & \\
\hline $\begin{array}{l}\text { 9. Non-verbal } \\
\text { intimacy }\end{array}$ & $4.63(1.30)$ & .85 & $.49^{* * *}$ & $.48 * *$ & $-.48^{* * *}$ & $.29^{* * * *}$ & $.46^{* * *}$ & $.47^{* * * *}$ & $.42^{* * *}$ & $.62^{* * * *}$ & - & & & & & \\
\hline 10. Intergroup warmth & $\begin{array}{l}65.55 \\
(21.13)\end{array}$ & - & $.3^{* * *}$ & $.35^{* * * *}$ & $-.38^{* * *}$ & $.44^{* * * *}$ & $.56^{* * *}$ & $.39^{* * * *}$ & $.29^{* * * *}$ & $.35^{* * *}$ & $.42^{* * * *}$ & - & & & & \\
\hline $\begin{array}{l}\text { 11. Past romantic } \\
\text { engagement }\end{array}$ & $2.53(1.95)$ & - & $.36^{* * * *}$ & $.30^{* * * *}$ & $-.13^{*}$ & .08 & $.17^{* * *}$ & $.33^{* * * *}$ & $.34^{* * * *}$ & $.39^{* * * *}$ & $.28^{* * * *}$ & .10 & - & & & \\
\hline 12. Gender ${ }^{\mathrm{a}}$ & - & - & -.11 & -.10 & .01 & .02 & -.11 & $-.14 *$ & $-.20^{* * *}$ & -.001 & .01 & -.04 & $-.23^{* * *}$ & - & & \\
\hline $\begin{array}{l}\text { 13. Sexual } \\
\text { Orientation }^{\mathrm{b}}\end{array}$ & - & - & -.003 & .03 & $-.15^{*}$ & -.02 & .10 & -.02 & -.01 & -.01 & .08 & .06 & .05 & -.09 & - & \\
\hline 14. Attraction & $4.52(1.67)$ & .96 & $.45^{* * * *}$ & $.55^{* * *}$ & $-.30^{* * * *}$ & $.32^{* * * *}$ & $.50^{* * * *}$ & $.54^{* * * *}$ & $.53^{* * * *}$ & $.56^{* * *}$ & $.51^{* * * *}$ & $.51^{* * * *}$ & $.45^{* * * *}$ & $-.25^{* * *}$ & .01 & - \\
\hline
\end{tabular}

${ }^{*} p<.05, * * p<.01, * * * p<.001{ }^{*}{ }^{\mathrm{a}} 1=$ Female, $0=$ Male and Non-Binary, ${ }^{\mathrm{b}} 1=$ Heterosexual, $0=$ Other 


\section{Figure 1}

A depiction of the path analysis examining the links between cross-race friendships and cross-race attraction

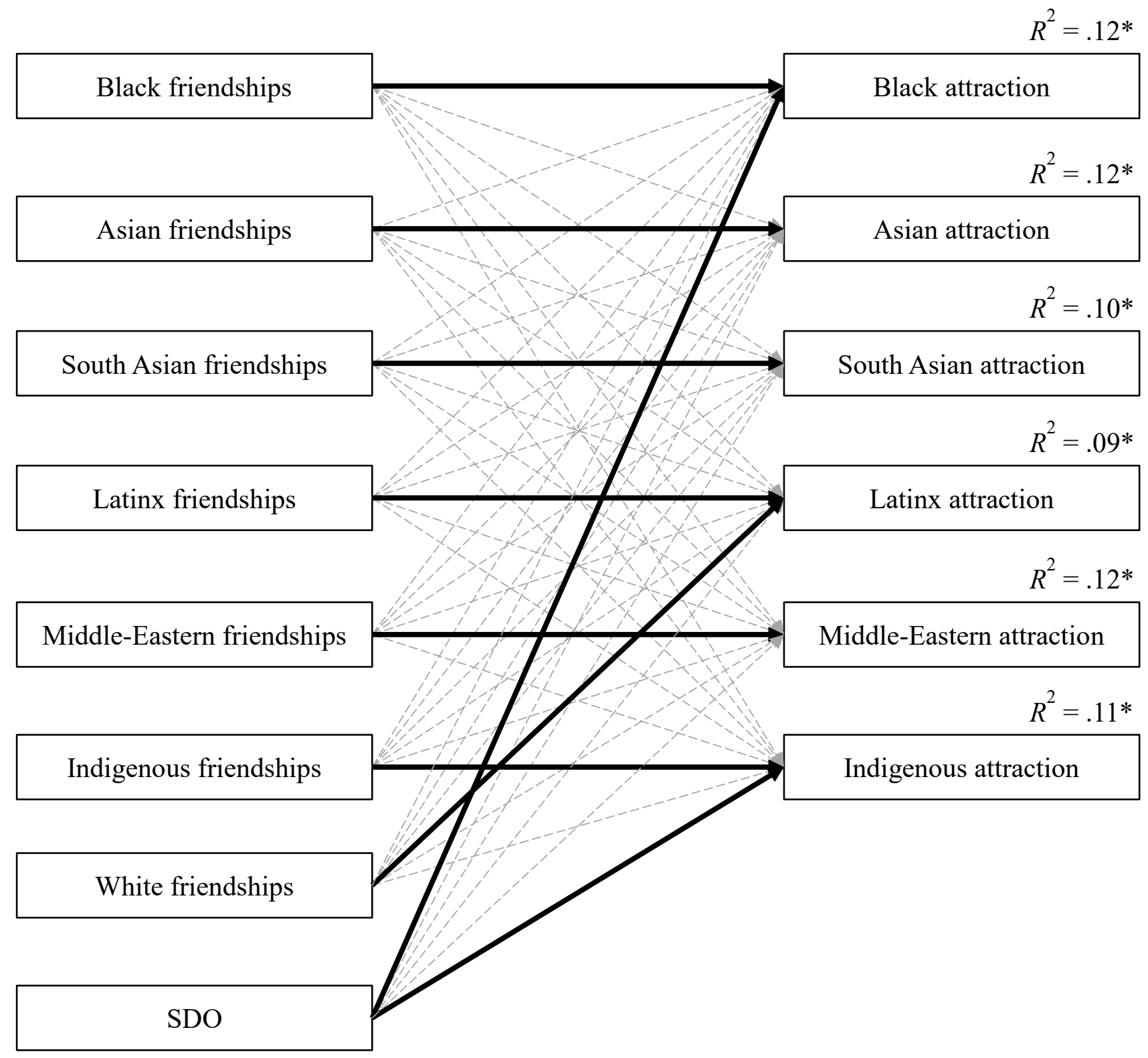

Note. Bolded lines represent significant pathways $(p<.05)$. For ease of reading, covariates and error terms were omitted. 
Figure 2

The proposed model of the link between cross-race friendship and cross-race romantic attraction

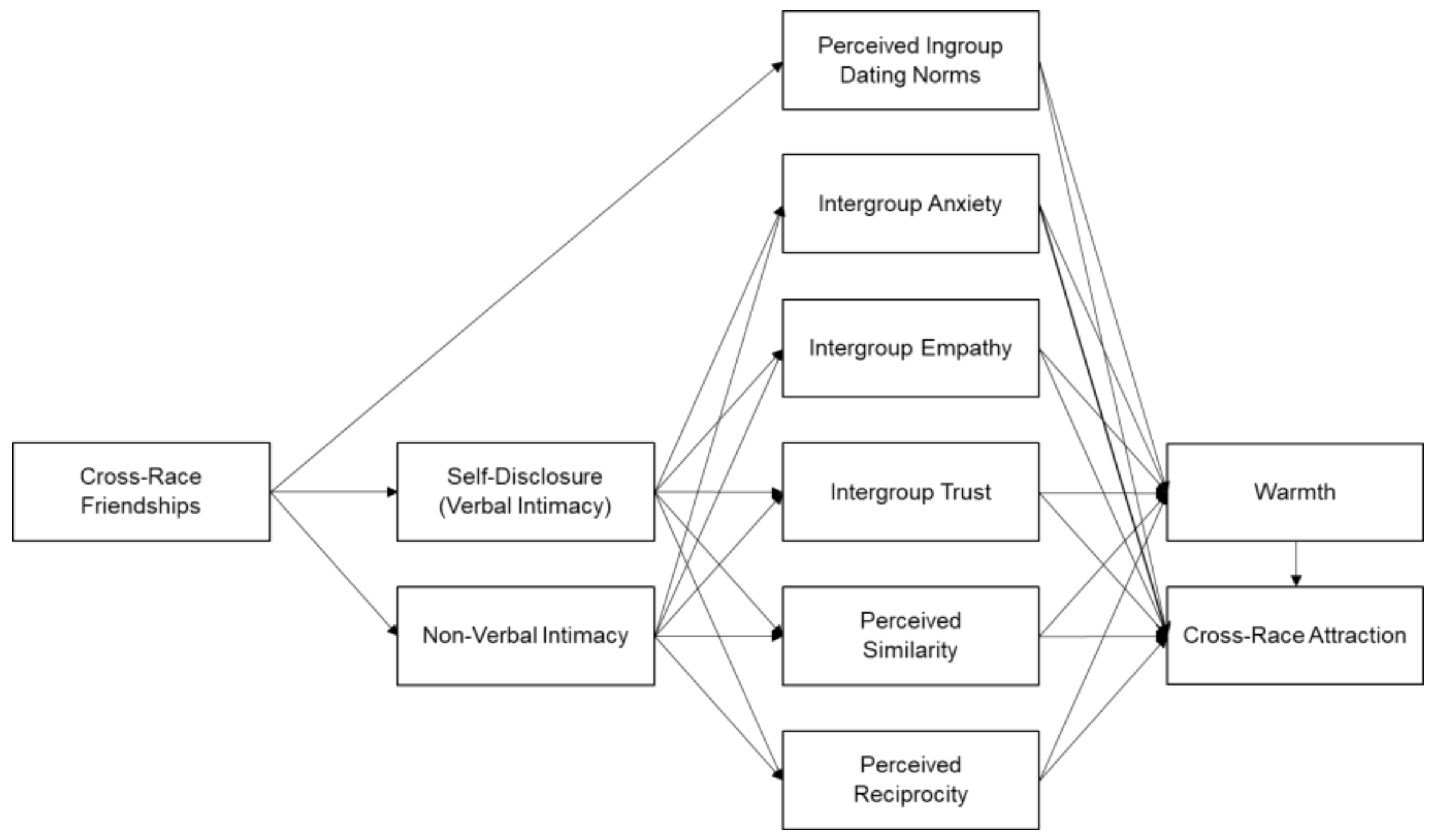




\section{Figure 3}

A forest plot showing the combined indirect effects and bootstrapped 95\% confidence intervals of cross-friendships on attraction via ingroup dating norms (IDN), self-disclosure (SD), and non-verbal intimacy (NV)

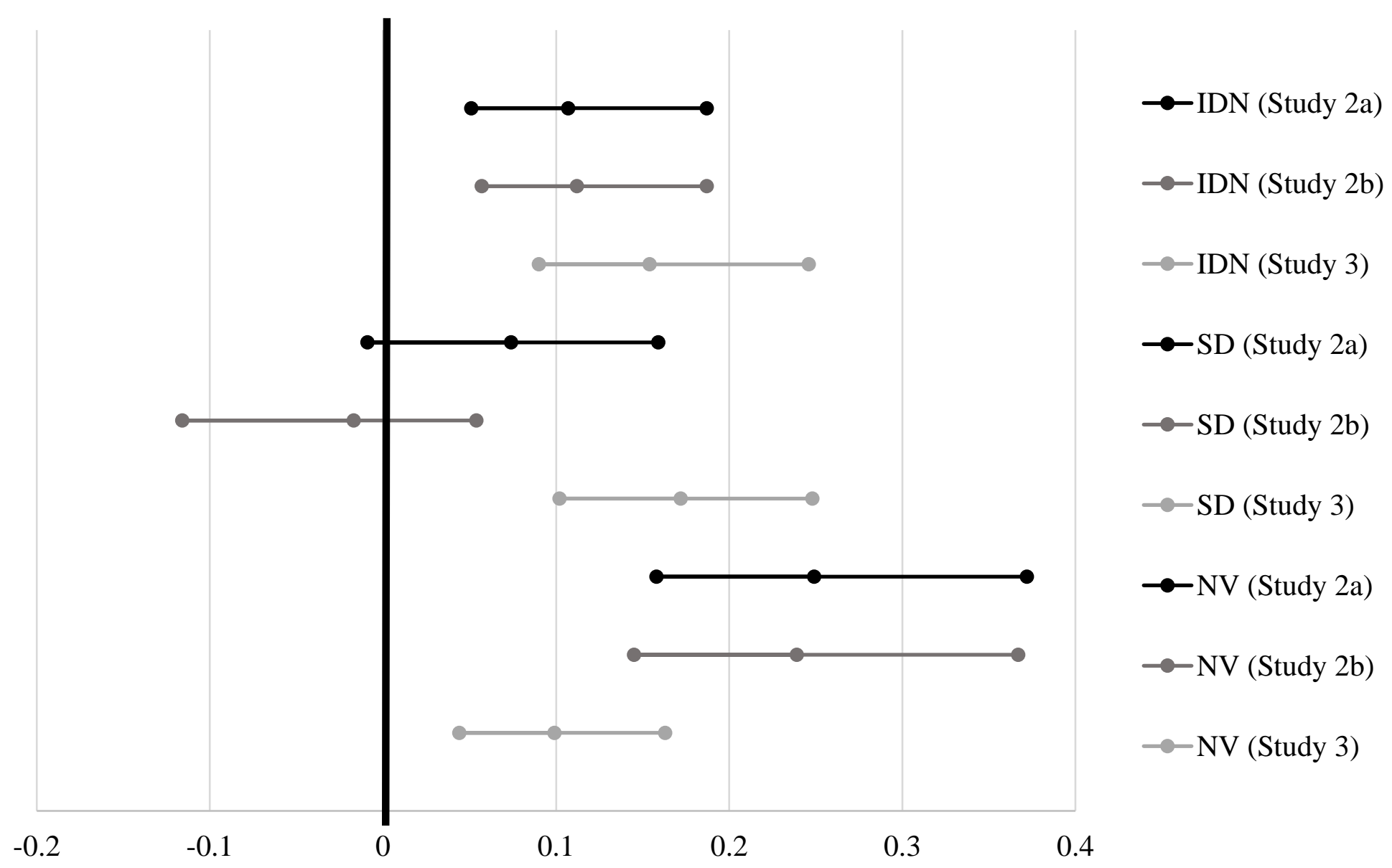

